\title{
22. PETROLOGY AND GEOCHEMISTRY OF DSDP LEG 16 BASALTS, EASTERN EQUATORIAL PACIFIC
}

\author{
Robert S. Yeats, Department of Geology, Ohio University, Athens, Ohio, \\ Warren C. Forbes, Department of Geological Sciences, University of Illinois at Chicago Circle, Chicago, Illinois, \\ and \\ G. Ross Heath, and Kenneth F. Scheidegger, School of Oceanography, Oregon State University, Corvallis, Oregon.
}

\begin{abstract}
Basalts cored on DSDP Leg 16 fall into two groups. Those from the west flank of the East Pacific Rise (DSDP 159-163) are geochemically homogeneous tholeiites. In contrast, the Panama Basin samples (DSDP 155-158) range from alkali basalts to tholeiites and may have formed over a mantle "hot spot" rather than at a mid-ocean ridge. Based on core relationships, all the Leg 16 basalts are extrusive.

DSDP 163 penetrated 18 meters of basalt made up of seven cooling units with chilled glassy margins. Even in this Campanian (Cretaceous) sequence, severe alteration affects only the uppermost few centimeters. Sideromelane appears particularly resistant to low-temperature alteration. Microprobe analyses of spheroidal "globules" (probably spherulites) at the inner margins of sideromelane masses show bimodal chemical compositions: reddish spherulites are enriched in $\mathrm{Na}_{2} \mathrm{O}, \mathrm{Al}_{2} \mathrm{O}_{3}$ and $\mathrm{SiO}_{2}$, whereas opaque ones are enriched in $\mathrm{MgO}$ and $\mathrm{FeO}$ relative to glass. The bulk composition of the "globular" zone is the same as that of the bulk rock, pointing to partitioning in situ.
\end{abstract}

\section{INTRODUCTION}

Eight holes drilled during Leg 16 reached basaltic basement. Three of these achieved significant basement penetration, 17 meters at DSDP 155, 6 meters at DSDP 157, and 18 meters at DSDP 163 . At the other sites where basement was reached (DSDP 158-162), penetration was slight and recovery was limited to basalt fragments at the sediment-basement contact.

Most of the literature on deep-sea basalts describes dredged samples, many of which are weathered and are either quite young or are exposed by virtue of their unusual topographic position, such as on basaltic pinnacles or at the edges of fracture zones. Ocean floor basalts covered with a relatively thick sedimentary sequence had not been sampled prior to deep-sea drilling. The nature of site selection in deep-sea drilling makes it likely that basalt samples collected through drilling may differ significantly from dredge-haul samples. In the selection of drill sites, an attempt is made to find areas of low basement relief with a uniform sediment cover; therefore, samples of basement from such sites are likely to be representative of large areas of sediment-covered ocean floor.

Each site chapter contains a relatively complete description of the basalt. This chapter summarizes these descriptions and treats petrographic characteristics common to more than one site in more detail. It also lists bulk rock chemical analyses and microprobe analyses of basalt glass and of individual mineral grains.
Much of the paper deals with DSDP 163, where recovery of an unusually complete section permits a relatively detailed evaluation of the relationships of petrography and geochemistry to position within individual cooling units in a basalt sequence.

Velocity determinations by N.I. Christensen (Chapter 24), magnetic studies by D.F. Heinrichs (Chapter 23), and K-Ar dating of DSDP 163 samples by J. Dymond (Chapter 25) are described elsewhere in this volume.

\section{OPERATIONS AND CORE RECOVERY}

The depth to which the Glomar Challenger was able to penetrate basement on Leg 16 appeared to be controlled by both the thickness and degree of induration of overlying sediments and the type of bit used. At DSDP 158 to 162 , where only fragments of the basement surface were recovered, sediment thicknesses average 187 meters, whereas at DSDP 155,157 , and 163 , sediment thicknesses average 410 meters. The thickest sedimentary sections drilled with poor basalt recovery were 322 meters at DSDP 158 and 244 meters at DSDP 161. These sites, however, together with DSDP 159,160 , and 162 , were drilled with regular button bits (with sealed bearings in the case of 161 and 162), whereas DSDP 155, 157, and 163 were drilled with a new type of button bit with longer shaped inserts.

Poor recovery may result from the contrast in lithification between sediment and basalt (reflected in markedly 
different drilling rates) and from inadequate sidewall support of the drill string by sediments. Thus, in poorly consolidated sediment, when drilling weight is increased in an attempt to penetrate the basement, the bit apparently "walks" around the sediment-basalt contact rather than penetrating it, resulting in sidewall friction, high torque, and termination of drilling due to the danger of twist-off. This situation prevailed at DSDP 158 to 162 . In contrast, the sediments at DSDP 155,157 , and 163 provided adequate sidewall support due to greater lithification of carbonate rocks and to chert interbeds. Consequently, the bit remained in position and achieved basement penetration.

Core recovery at DSDP 163 probably would have been even greater if the core barrel had been equipped with hard-rock core catchers. Damage to the catchers led to part of Core 29 falling out of the barrel as the drill string was pulled off bottom during change of core barrels. Thus it was impossible to get to bottom to take Core 30; the cones on the bit apparently were lost in an effort to mill up the lost portion of Core 29.

If significant penetration of the basement is to be achieved, the site should be one overlain by several hundred meters of sediment. Hard-rock core catchers will be needed and re-entry will probably be necessary. Bits with shaped inserts were successful in achieving basalt core recovery. It may be advisable, however, to use other types of bits for re-entry drilling in basement alone.

\section{GENERAL GEOLOGIC SETTING}

DSDP 155,157 , and 158 are on submarine ridges within and adjacent to the Panama Basin. DSDP 159 to 162 are on the west flank of the East Pacific Rise. The ages of sediments immediately overlying basalt agree closely with the ages predicted from the results of Leg 9 of the project. DSDP 163 may also be on the flank of the East Pacific Rise, although the age of sediment immediately overlying basalt is considerably older than that predicted from the sea floor spreading model. Despite the different geologic settings, no significant lithologic or petrographic differences could be recognized. All the basalts are geochemically similar except the one from DSDP 155.

\section{DSDP 163}

Only DSDP 163 of the west-flank East Pacific Rise sites achieved significant basement recovery. Fragments recovered from the other sites resemble rock types from 163, so that a complete description of DSDP 163 may be representative of the other sites as well.

Basalt was reached at 5596 meters and was cored to a depth of 18 meters. Two cores recovered 7.4 meters (1.3 $\mathrm{m}$ in Core 28; $6.1 \mathrm{~m}$ in Core 29; Figure 1). The failure of the bit to reach bottom to cut Core 30 indicates that most and perhaps all of the loss from Core 29 was from its base. Thus, the 6.1 meters of core recovered probably represent a continuous section. Whether the 7.7 meters lost from Core 28 are distributed among the six breaks within the core or are essentially restricted to one of them cannot be determined.

The basalt is divided into seven cooling units separated by 1 - to $2-\mathrm{cm}$ zones of black glass (Figure 1). The glass zones dip at 15-70 degrees, suggesting that the cooling

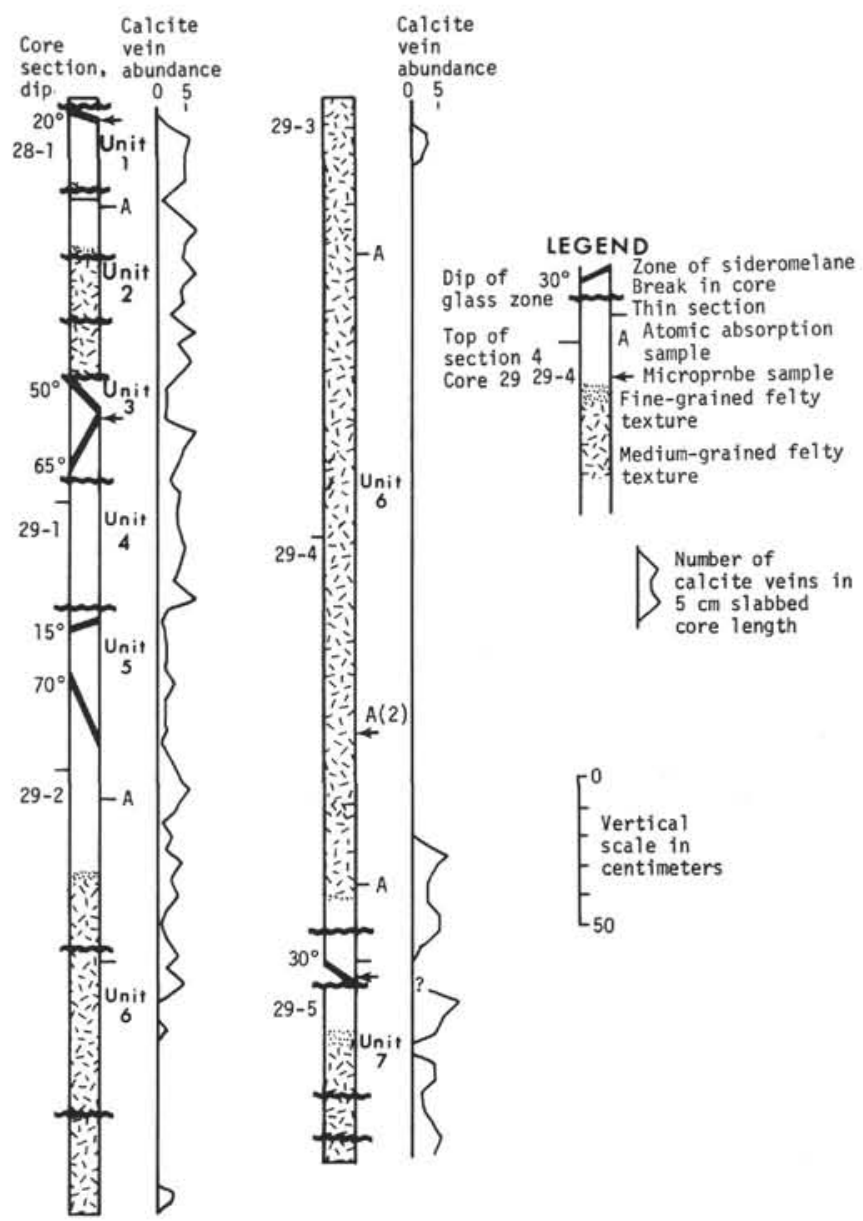

Figure 1. Basalt recovered at DSDP 163. Individual flow units are bounded by black glass. Core 29 probably represents nearly complete recovery; loss of section in Core 28 is at one or more of the breaks shown.

units, or at least the thinner ones, are pillows. Units vary in thickness from 14 to $470 \mathrm{~cm}$, with the thinner units near the top of the core.

Aside from the glass zones, there are no megascopic structural features associated with cooling unit emplacement. However, several other megascopic relationships are clearly related to distance from the glassy margin. These are (a) abundance of calcite veins, (b) degree of brown and greenish gray alteration, and (c) development of felty texture due to late-formed lathlike plagioclase. Figure 1 shows the number of calcite veins recognized per $5-\mathrm{cm}$ length of slabbed core surface. Calcite veins are virtually absent from $100 \mathrm{~cm}$ below the top of the largest cooling unit to $50 \mathrm{~cm}$ above its base. No vein-free central zone is present in the other cooling units, probably because none of them exceeds $70 \mathrm{~cm}$ in thickness. The calcite veins are $0.25-4 \mathrm{~mm}$ in thickness (except for a $15-\mathrm{mm}$ horizontal calcite vein at the top of unit 7) and are irregular in orientation, often anastomosing and cross-cutting. Some of the veins contain serpentine in addition to calcite.

Basalt alteration is strongest adjacent to calcite veins and glassy margins. Near the margins, the basalt is dusky yellow, moderate yellowish brown, and olive gray in color. 
Farther away, greenish gray and medium light gray dominate. Much of the discoloration of the rock parallels the veins. Even in the vein-free portion of unit 6, however, there is evidence of alteration; natural fractures are greenish gray or greenish black in color and have a talcose feel, and thin sections have a browner tint than very fresh Quaternary basalt from mid-ocean ridges. Evidence of alteration is seen also in the water contents of analyzed samples. Three analyses in the altered zones contained 0.89-1.82 per cent $\mathrm{H}_{2} \mathrm{O}+$ water. Very fresh, young midocean basalt contains $<0.5$ per. cent $\mathrm{H}_{2} \mathrm{O}+$. Alteration may have proceeded via fractures formed on the hardened margins of the flow while the interior was still molten, allowing solutions related to solidification of the interior or hot seawater to permeate these fractures and alter the wall rock (Corliss, 1971). Alternatively, the tendency to form fractures after cooling may have been greater in the glassy margins than in the crystalline center, so that the alteration and calcite vein formation are related to fracture permeability.

Textural gradation from glassy margin to felty-textured core in each unit occurs both downward from the glassy top across a broad zone and upward from the glassy base across a narrow zone (Figure 1). The gradation downward from glass to felty basalt in unit 6 is about $50-\mathrm{cm}$ thick, and the gradation upward from the base of the same unit is about $25 \mathrm{~cm}$ thick. The gradations downward in units 1,2 , and 7 are narrower, $15-20 \mathrm{~cm}$ thick, possibly due to lesser overall cooling unit thickness.

The outer margin of the pillows consists of three distinct zones, the glass, globule, and aphanitic zones, with an aggregate thickness of $2-4 \mathrm{~cm}$. The pillow margins are similar in appearance to those described by Moore (1966) except for the absence of manganese oxide and palagonite zones. The outermost zone is a black, glassy margin, 1-2 $\mathrm{cm}$ thick, with a conchoidal fracture pattern. The glass is cut by thin greenish olive to pale olive calcite-serpentine veins that are subparallel to the margin. In thin section, the glass is light brown and transparent and contains scattered microlites of plagioclase and less common phenocrysts of olivine $\left(\mathrm{FO}_{86}\right)$ (Figure 2). The glass is similar to the sideromelane collected from the Pacific Ocean floor on the H.M.S. Challenger voyage and described by Murray and Renard (1891); it also resembles sideromelane from the Columbia Plateau (Peacock and Fuller, 1928) and from the submerged flanks of Kilauea (Moore, 1966). The glass zone is gradational into the globule zone with the appearance of small opaque and reddish brown globules $0.1-0.3 \mathrm{~mm}$ in diameter scattered within the glass; this corresponds to the "speckled brown glass" layer of Moore (1966). The globules form around nuclei of microphenocrysts of plagioclase but rarely around olivine. Individual globules grade into sideromelane across a pitted zone about 25 microns wide. X-ray analysis of a small chip from the speckled glass zone containing about 50 per cent (by volume) globules shows that the globules are microcrystalline aggregates of plagioclase and pyroxene. Unfortunately, it was not possible to individually characterize each type of globule by X-ray diffraction.

The globules increase in size and number at the expense of sideromelane over a 1- to 2-mm distance beyond which

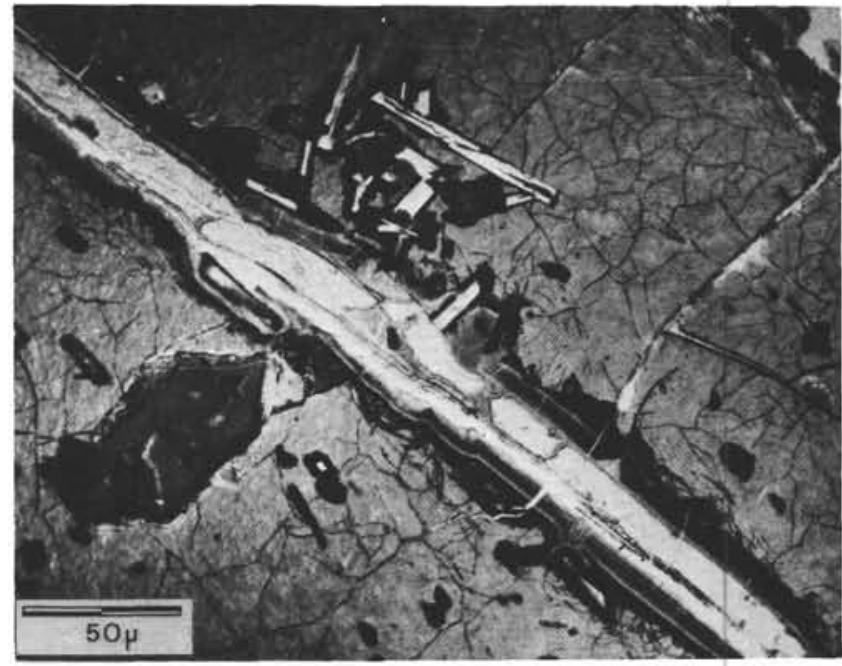

Figure 2. Inclined base of cooling unit 3, DSDP 163. Margin of cooling unit in upper right corner. Mainly sideromelane with conchoidal fracture, and opaque glass rimming pre-emplacement laths of labradorite. Plagioclase laths and serpentine veins tend to parallel unit margin. Large dark area at left is serpentine pseudomorph after olivine.

sideromelane is absent; this marks the outer edge of the globule zone (Figure 3). This zone, about 5 -mm thick, consists of reddish brown and opaque globules with average diameters of about $0.6 \mathrm{~mm}$. The reddish brown globules have a radial, undulose extinction typical of spherulites and are composed of microcrystalline material. Many of the globules have nuclei of plagioclase microlites that are compositionally and texturally similar to microlites in the glass zone.

The globule zone grades into aphanitic basalt over a narrow interval. The transition is marked by a loss in definition of the globule boundaries and by development

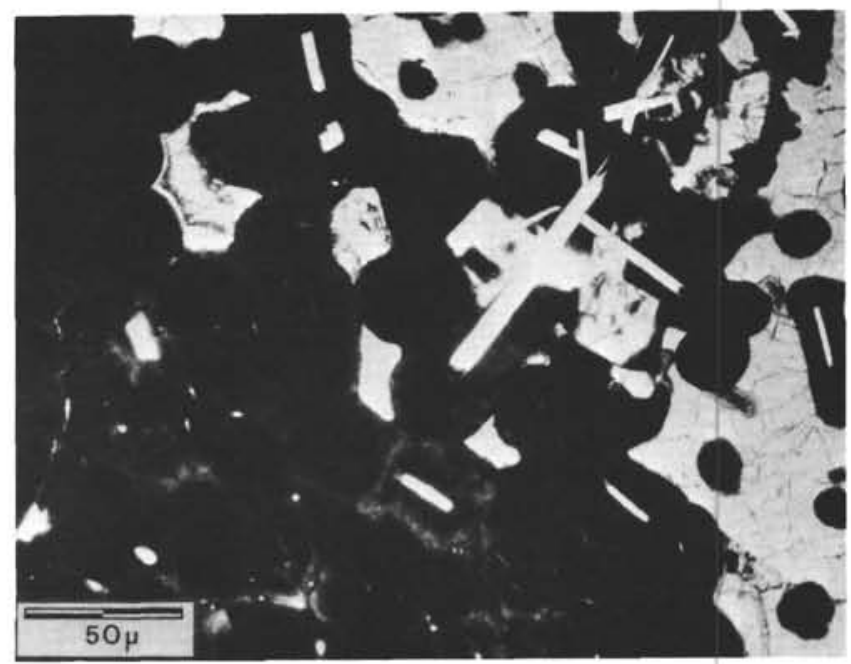

Figure 3. Ten $\mathrm{mm}$ above base of cooling unit 3, DSDP 163. Coalescing globules of opaque and translucent glass form an increasing percentage of the matrix away from the unit margin. Sideromelane occurs only in interstitial areas. Plane polarized light. 
of variolitic texture. Two types of varioles are present: (a) reddish brown moderate-relief varioles with low first order interference colors (incipient pyroxene, Figure 4); and (b) sheaflike intergrowths of plagioclase and opaque minerals. Several centimeters away from the glass, the pyroxene varioles have middle first order interference colors and inclined extinction; these are low in opaques. The plagioclase sheafs with dusty opaque minerals are commonly dominated by a single lath which develops long extensions of the 010 face similar to a hopper crystal (Figure 5). Other plagioclase grains grow as skeletal crystals with a core of partly devitrified glass (Figure 5). Skeletal plagioclase is also found in the holocrystalline interior of the unit, where the core is fine-grained augite and iron oxide

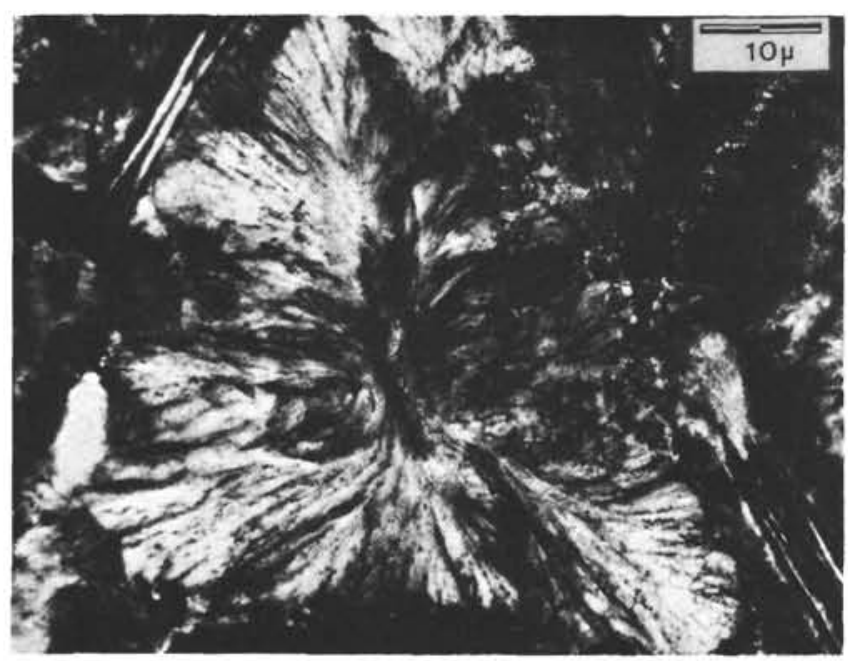

Figure 4. Two cm above base of cooling unit 3, DSDP 163. Sheaflike variole of incipient pyroxene. Hopper crystal of plagioclase at margin. Plane polarized light.

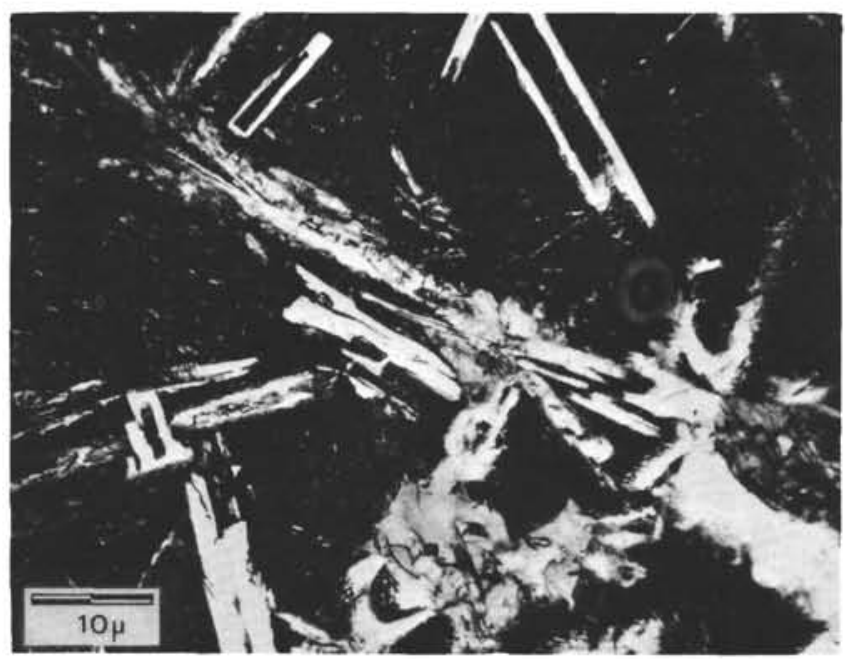

Figure 5. Fine-grained altered basalt $30 \mathrm{~cm}$ below top of cooling unit 6, DSDP 163. Skeletal laths of labradorite have cores filled with glass; extensions of 010 face give laths the appearance of hopper crystals. At bottom center, euhedral olivine is pseudomorphed by serpentine. Plane polarized light. rather than glass (Figures 6, 7, 8). Similar sheaf-like pyroxene and hopper crystals of plagioclase are described in Atlantic basement cores from DSDP Leg 11 (Bryan, 1972).

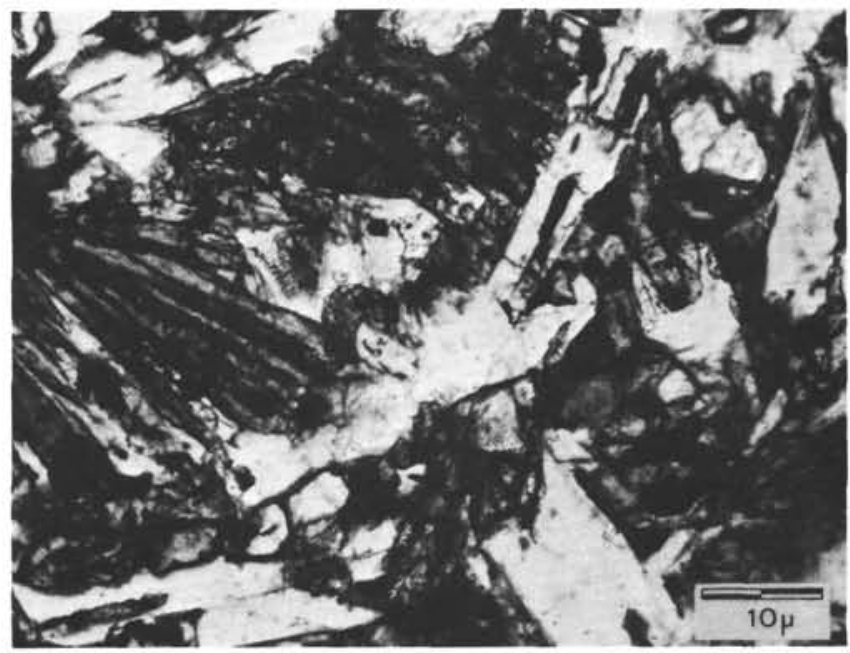

Figure 6. Center of cooling unit 6, DSDP 163. Lateformed, sheaflike augite (left), small olivine grains (highrelief), labradorite laths. Matrix is holocrystalline. Plane polarized light.

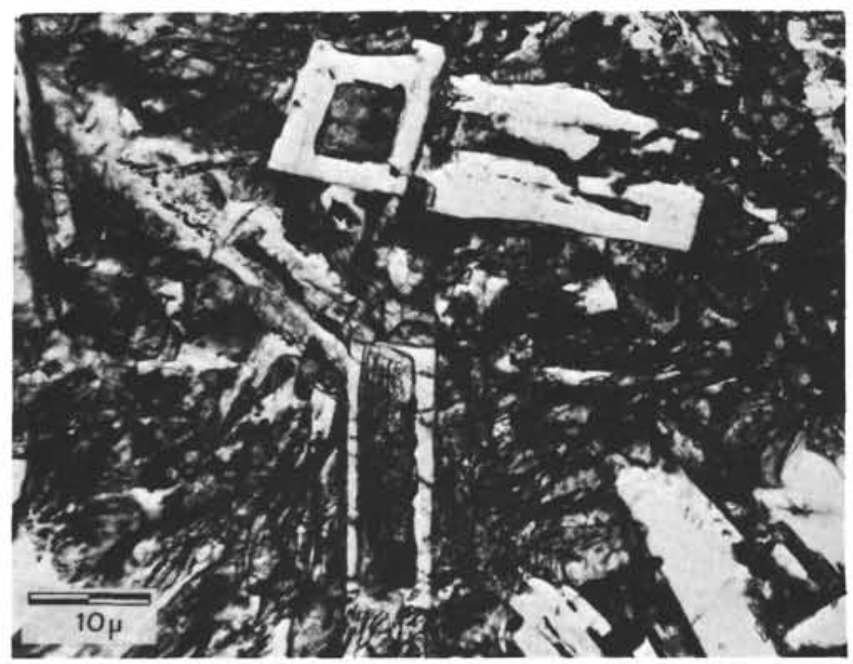

Figure 7. Center of cooling unit 6, DSDP 163. Skeletal labradorite similar to that of Figure 5 but cores are anhedral augite and opaque minerals. Matrix has same composition as plagioclase cores. Plane polarized light.

Quantitative analyses of globules and sideromelane glass were made in polished thin section of samples from three glassy margins from DSDP 163, using a Materials Analysis Company MAC-5 electron probe microanalyzer with a 38.5 degree take-off angle, at the University of Illinois at Chicago Circle. The operating conditions were as follows: accelerating potential $15 \mathrm{kv}$; specimen current on brass, $0.04 \mu \mathrm{A}$; beam diameter, 1-2 microns; counting 


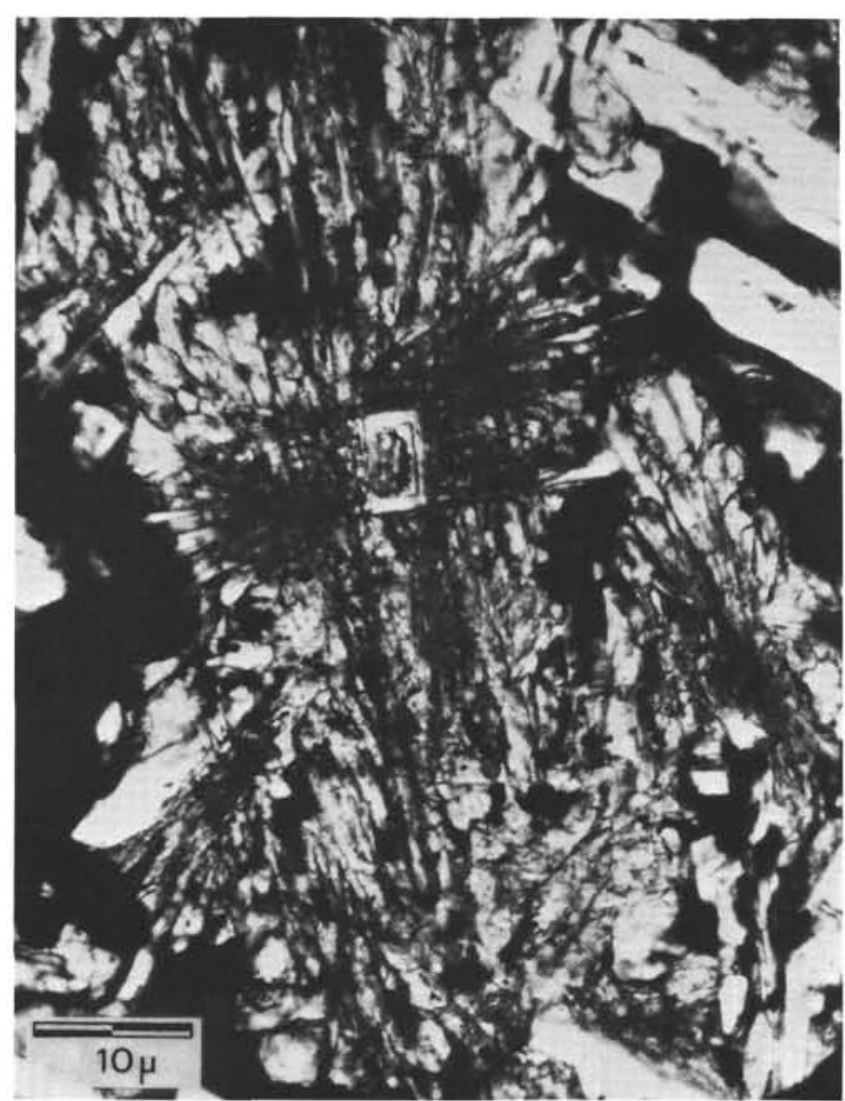

Figure 8. Thirty $\mathrm{cm}$ above base of cooling unit 6, DSDP 163. Large variole of augite radiating from skeletal crystal of labradorite, which itself has an augite core. Plane polarized light.

time, 10 seconds; experimental drift, as determined by comparison of standard count rates before and after each analysis, was less than one per cent. Corrections were made for drift, deadtime, background, mass absorption, fluorescence, and atomic number using an EMPADR VII program (Rucklidge and Gasparrini, 1969).

These analyses are presented in Table 1. Of significance are the compositional differences between the two types of globules. Compared to the glass, the reddish globules are enriched in $\mathrm{SiO}_{2}, \mathrm{Al}_{2} \mathrm{O}_{3}$, and $\mathrm{Na}_{2} \mathrm{O}$, whereas the opaque globules are deficient in $\mathrm{SiO}_{2}, \mathrm{Al}_{2} \mathrm{O}_{3}$, and $\mathrm{Na}_{2} \mathrm{O}$ and are enriched in $\mathrm{FeO}$ and $\mathrm{MgO}$ (Figure 9). FMA and $\mathrm{Mg}-\mathrm{Ca}-$ Fe ternary diagrams (Figures 10 and 11) show that the glass is intermediate in composition between the two globule types. Within experimental error, little or no variation in the composition of each globule type is found within a sample. Each globule itself is compositionally uniform and, with each sample, the compositions of the globules are bimodal; i.e., there are no intermediate values. However, between samples, the degree of fractionation between the two globule types does vary. The fractionation of $\mathrm{SiO}_{2}$ $\mathrm{Al}_{2} \mathrm{O}_{3}, \mathrm{FeO}, \mathrm{MgO}$, and $\mathrm{Na}_{2} \mathrm{O}$ is most pronounced in $163-28-1(122-125 \mathrm{~cm})$ and least pronounced in 163-294(143-145 cm).

The low totals of several analyses may indicate the presence of $\mathrm{H}_{2} \mathrm{O}$ in the material or may be attributable to analytical error. Modal analysis of the globule layer in
Sample 163-28-1(17-19 cm) shows that the ratio of silicarich to silica-poor globules is $43: 57$. Using this ratio, a weighted average composition corresponds closely to the observed sideromelane glass composition for all elements except sodium, potassium, and calicum. The absence of correspondence for these elements may reflect submarine weathering.

The felty texture dominated by the lath-like plagioclase is shown in Figure 1 only where it is visible megascopically. Microscopically, it is observed as close as a few millimeters from the sideromelane margins. The petrographic changes from core to rim are shown in Table 2. The major changes from rim to interior of a given unit (best observed in unit 6) are (a) an increase in the length and lath-like character of the plagioclase, (b) an increase in the tendency of phenocrysts to form glomeroporphritic clusters, (c) an increase in the grain size of the pyroxene and opaque minerals, (d) a decrease in the degree of alteration of the olivine and groundmass, (e) a disappearance of vesicles, and (f) a change in the matrix from glassy and variolitic to holocrystalline. The grain size and composition of the olivine $\left(\mathrm{Fo}_{85-95}\right)$ and the composition of the plagioclase phenocrysts $\left(\mathrm{An}_{64.71}\right)$ remain constant from rim to center. Normally zoned plagioclase of about the same composition is seen in both rim and center, although the plagioclase grain size is larger in the center. Rare plagioclase laths are bent up to $50^{\circ}$.

Based on petrography, the crystallization history of the basalt can be summarized as follows:

1) Crystallization of olivine and some of the plagioclase prior to emplacement of cooling units. This is suggested by the presence of both of these minerals in the marginal glass and by the constancy of olivine properties from the rim to the interior of the cooling unit.

2) Emplacement of pillows and crystallization of the remaining plagioclase and all the pyroxene and opaque minerals. The pyroxene and opaque minerals formed later than most of the plagioclase, resulting in a diabasic texture. Incipient forms of these minerals tend to be skeletal and locally sheaf-like. Formation of vesicles in unit margins also occurred at this stage.

3) Fracture and vein formation, vesicle fillings, and alteration of early-formed minerals, especially olivine, to serpentine, calcite, and other secondary minerals. The presence of calcite pseudomorphs after olivine indicates local metasomatism, although there is no difference in whole-rock $\mathrm{CaO}$ content between altered and unaltered basalt.

\section{DSDP 159-162}

The other four sites on the west flank of the East Pacific Rise recovered only small amounts of basalt. Principal characteristics are tabulated in Table 3 . In general, these rocks (Figures 12,13) resemble those found in the upper part of Core 28, DSDP 163. The grain size of the major minerals is the same, as is the composition of the plagioclase. The pyroxene is similar except for low $2 \mathrm{~V}$ found at DSDP 159 and 160. Euhedral phenocrysts of pyroxene are found at DSDP 160, in contrast to the sheaf-like pyroxene at the other sites, including 163 . The sequence of crystallization of olivine, plagioclase, pyroxene, and opaques is the same as at DSDP 163. 
TABLE 1

Microprobe Analyses (Weight Per Cents) and Norms of Glass and Globules in Pillow Margins, DSDP 163

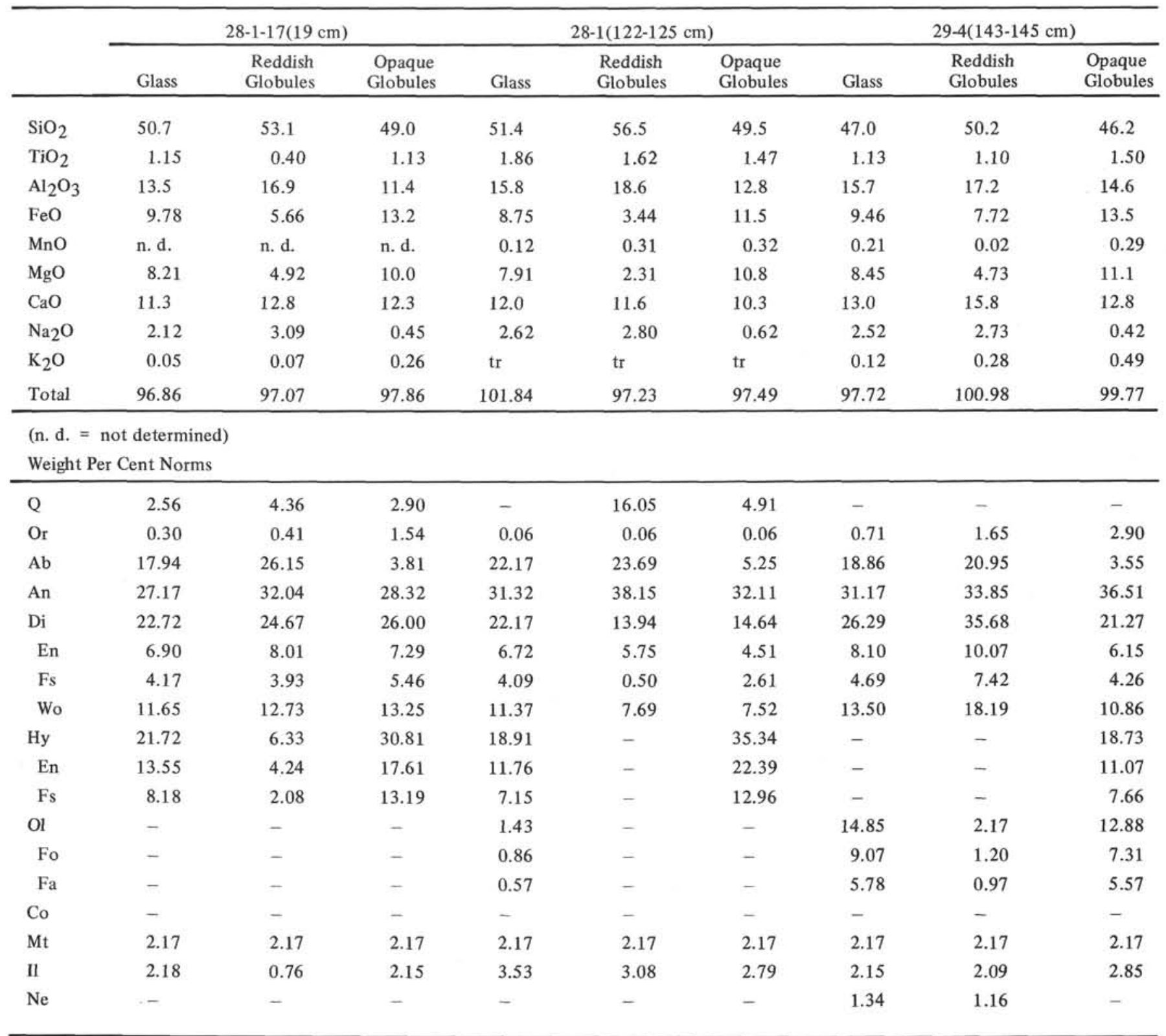

Vesicle diameters range from 0.05 to $0.9 \mathrm{~mm}$ and do not vary systematically with present depth below sea level. Some of the vesicles show two stages of filling, an early partial filling with very fine-grained, partly glassy basalt (Figure 14) and a later filling of zeolite or serpentine minerals. The early glassy basalt filling lies on the bottom of the vesicle only and is concave, reflecting the interfacial tension between the molten filling and the vesicle wall.

\section{DSDP 155, 157, AND 158}

These sites lie on the Coiba, Carnegie, and Cocos Ridges, respectively, in and around the Panama Basin. Although these features are considerably higher than the actively spreading Galapagos Rift, they are broad ridges rather than high-relief volcanoes or volcanic chains. These ridges may be traces of volcanic hot spot now centered in the Galapagos Islands (Morgan, 1971) split apart by the
Galapagos Rift (Holden and Dietz, 1972), or they may be the fragments of the ancestral Carnegie Ridge (van Andel et al., 1971). See Chapter 35, this volume, for a fuller discussion.

Basalts from these sites are similar in many respects to those from the west flank of the East Pacific Rise (Table 4). Opaque minerals form octahedra and octahedral chains; the most spectacular development of these in any of the Leg 16 rocks is at DSDP 158 (Figure 15). Pyroxene properties are similar (Figure 16, 17), although the color at DSDP 157 is light reddish brown in contrast to the light brown at other sites. The order of crystallization of major minerals is the same at all sites.

Yet there are differences, and one of these is greater variability. No olivine or olivine pseudomorphs were found in basalts at DSDP 158; these rocks contain the most sodic plagioclase found on Leg 16. In addition to 

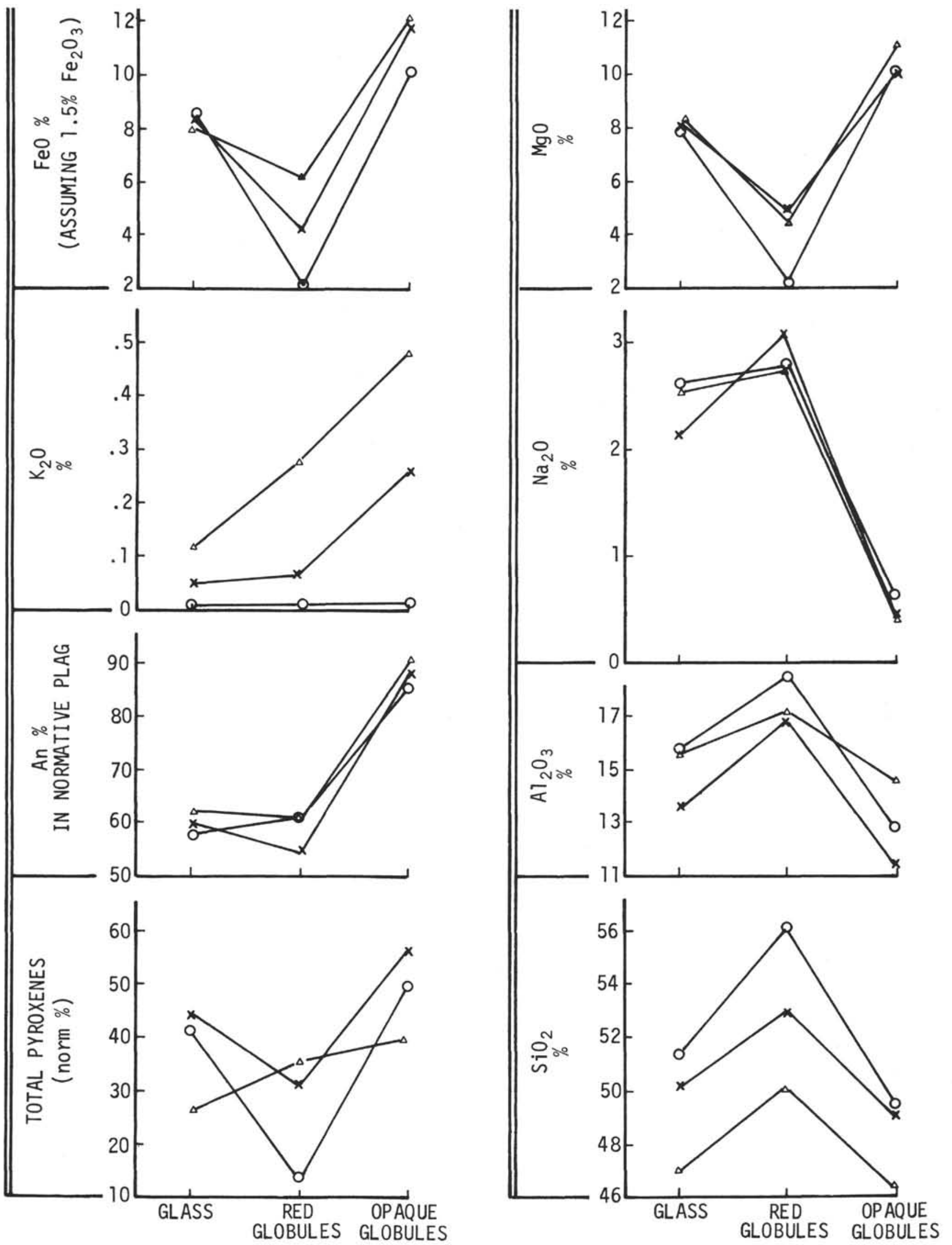

Figure 9. Chemical fractionation in opaque and red globules of DSDP 163 basalt, relative to homogeneous sideromelane (glass). $X ' s=163-28-1(17-19)$, circles $=163-28-1(122-125)$, triangles $=163-29-4(143-145)$. See Table 1 for analytical data. 


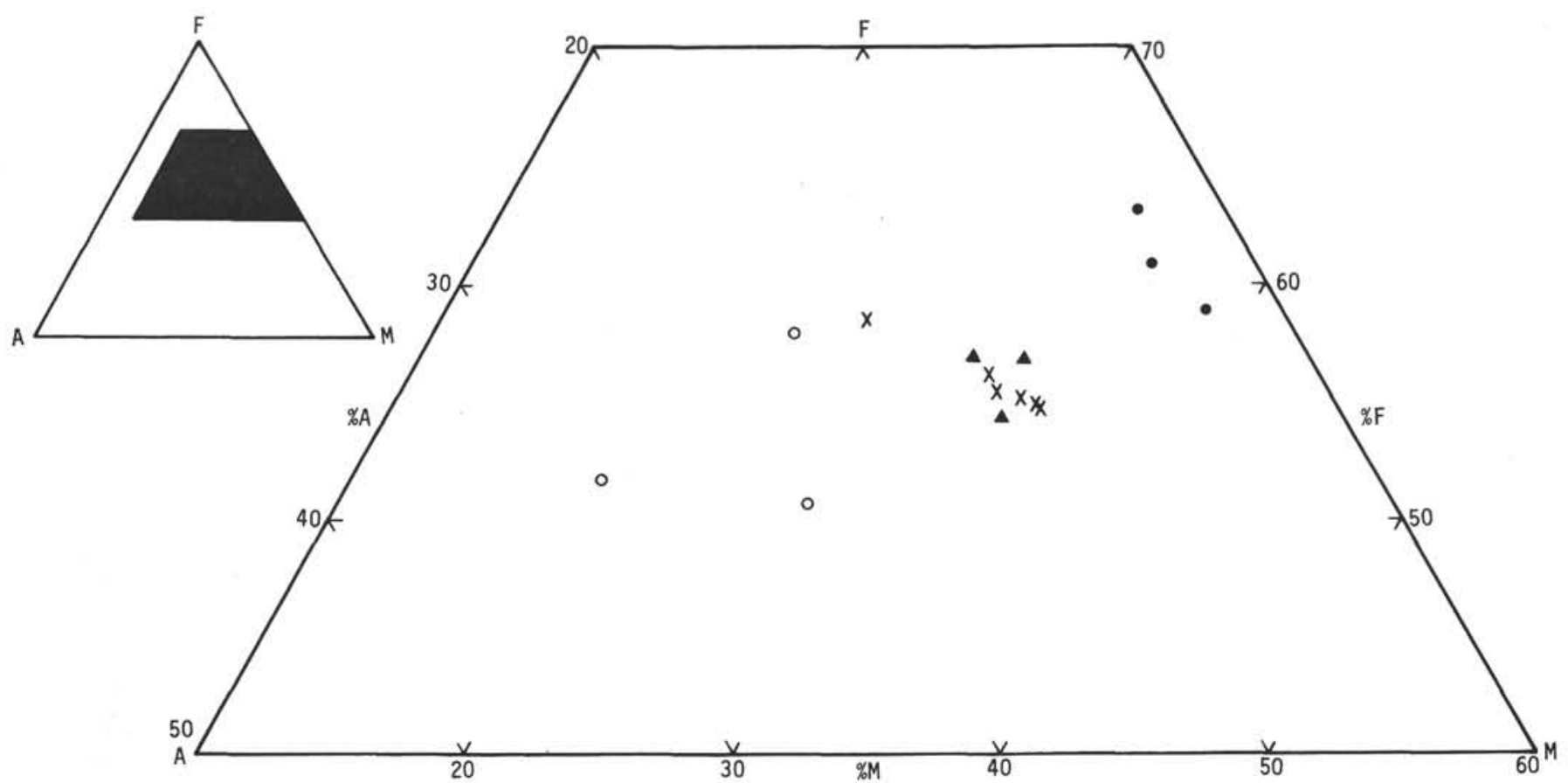

Figure 10. FMA atomic per cent plot of analyses of sideromelane (triangles), opaque globules (closed circles), reddish brown globules (open circles), and bulk rock samples (X's), showing similarity of sideromelane and bulk rock analyses and the differentiation trends of reddish brown and opaque globules, DSDP 163.

spinellid opaques, there are sulfides-pyrite in considerable quantity and possibly chalcopyrite and pyrrhotite in trace amounts (however, microprobe analysis of a sulfide grain from DSDP 158 showed it to be virtually pure $\mathrm{FeS}_{2}$ ). The pyroxenes did not develop from sheafs and varioles but

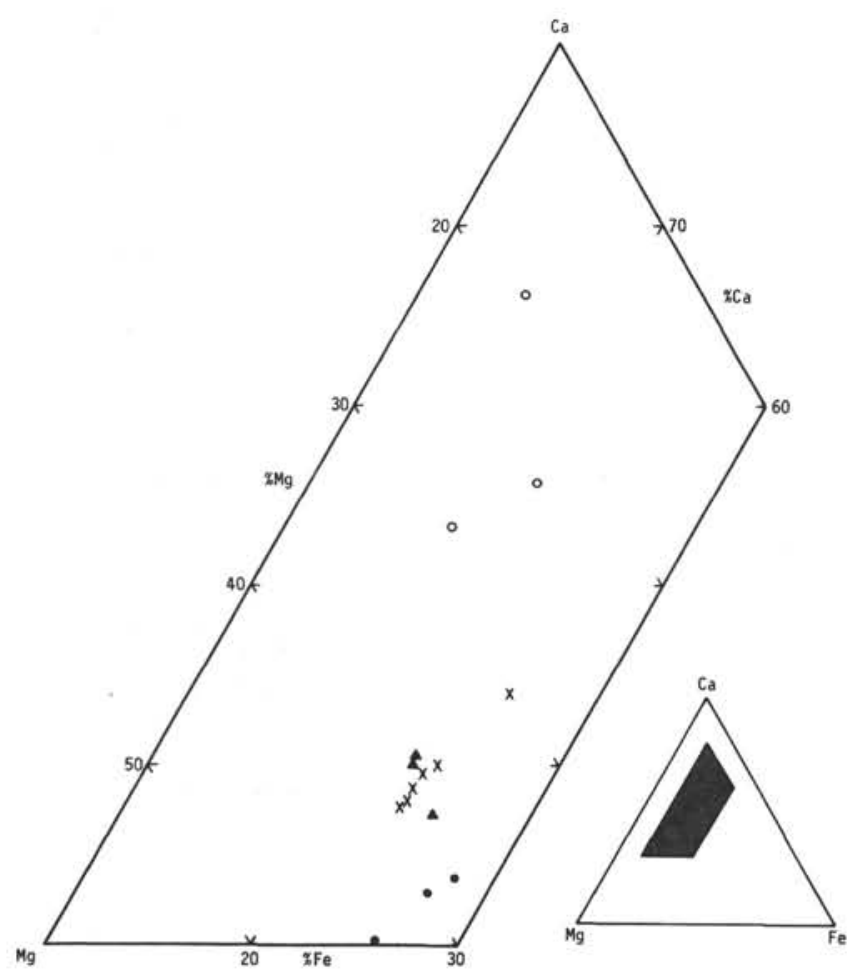

Figure 11. Ca-Mg-Fe atomic per cent plot of analyses, DSDP 163. Symbols same as Figure 10. crystallized interstitially, as in an ordinary diabase. Some of the largest plagioclase grains are equant with faint euhedral oscillatory zones (Figure 18); in some of the cores there are fine-grained euhedral prismatic inclusions of a pale brown mineral, possibly pyroxene. Near the top of the basement at DSDP 157, amygdaloidal glassy crusts have largely been replaced by fine-grained silica.

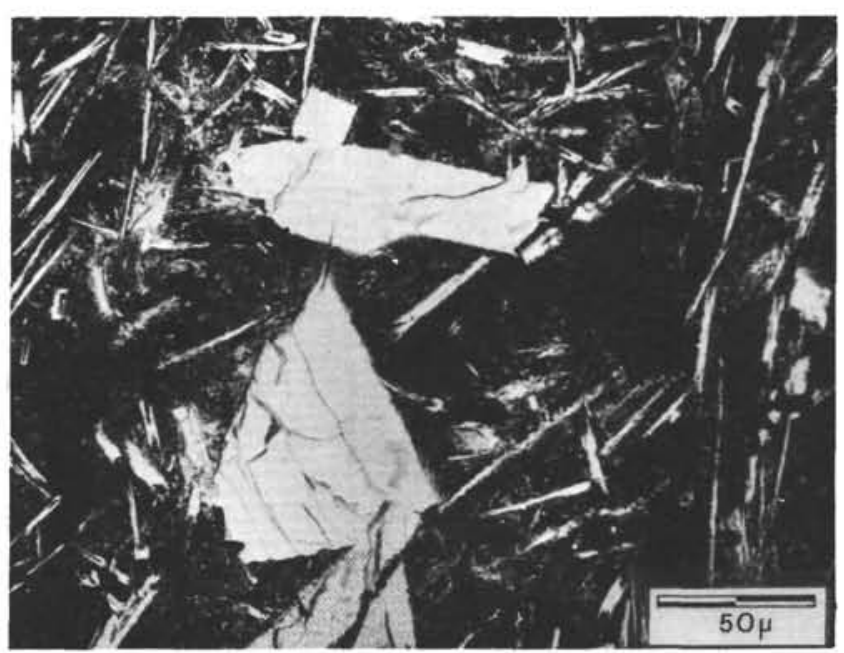

Figure 12. Bit sample, DSDP 161, west flank of East Pacific Rise. Fine-grained basalt, showing contrast between large, euhedral pre-emplacement labradorite and needlelike laths of labradorite that grew in place. Plane polarized light. 
TABLE 2

Petrographic Data from Thin Sections of Basalt, DSDP ]63

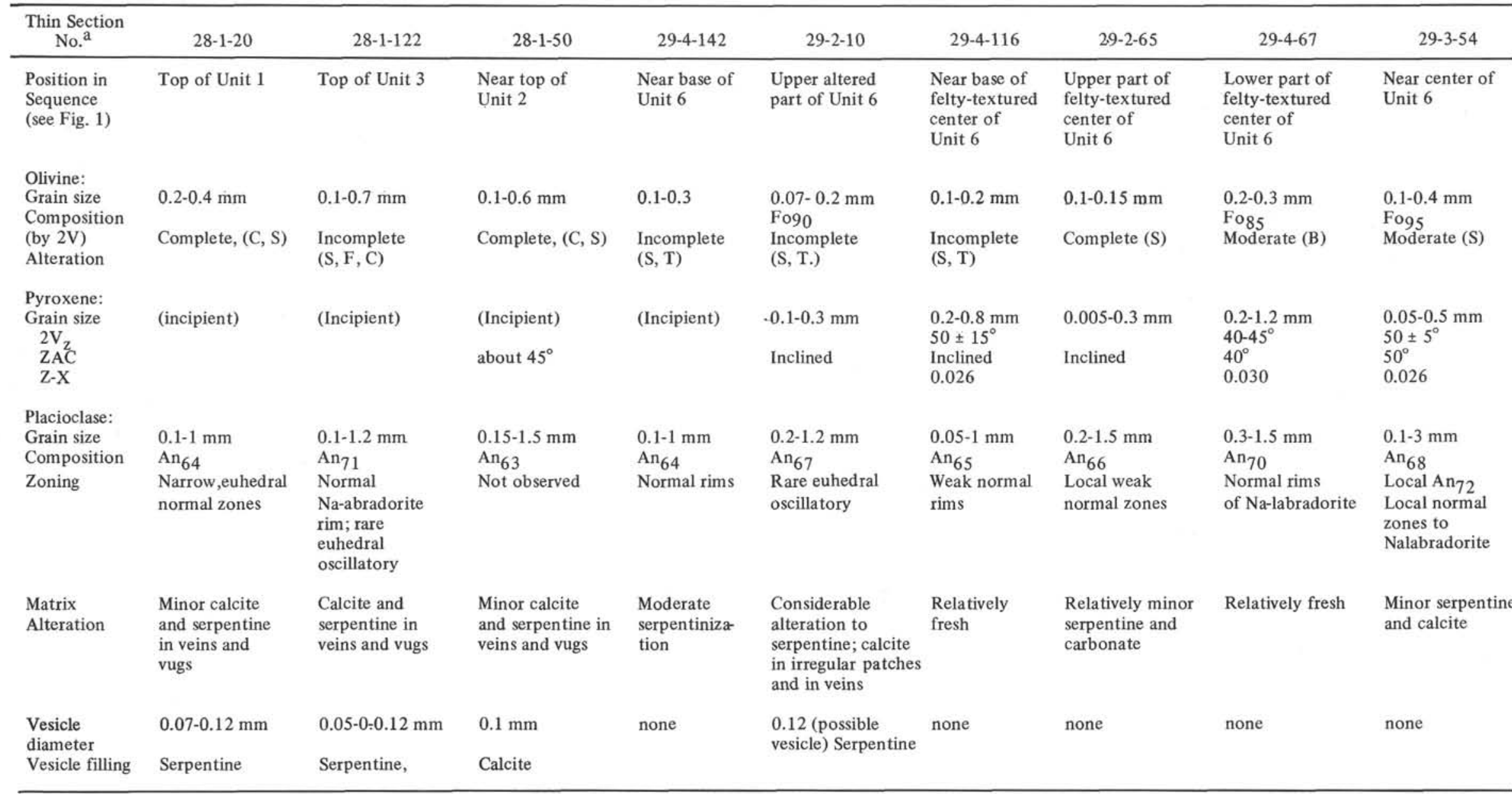

${ }^{a}$ Arranged from Left to Right According to Increasing Distance from the Glassy Margin of a Given Unit.

bAlteration symbols $; \mathrm{C}=$ carbonate, $\mathrm{S}=$ serpentine, $\mathrm{B}=$ bowlingite, $\mathrm{F}=$ iron oxide, $\mathrm{T}=$ talc. 
TABLE 3

Petrography of Basement Rocks at DSDP 159-162, West Flank of East Pacific Rise

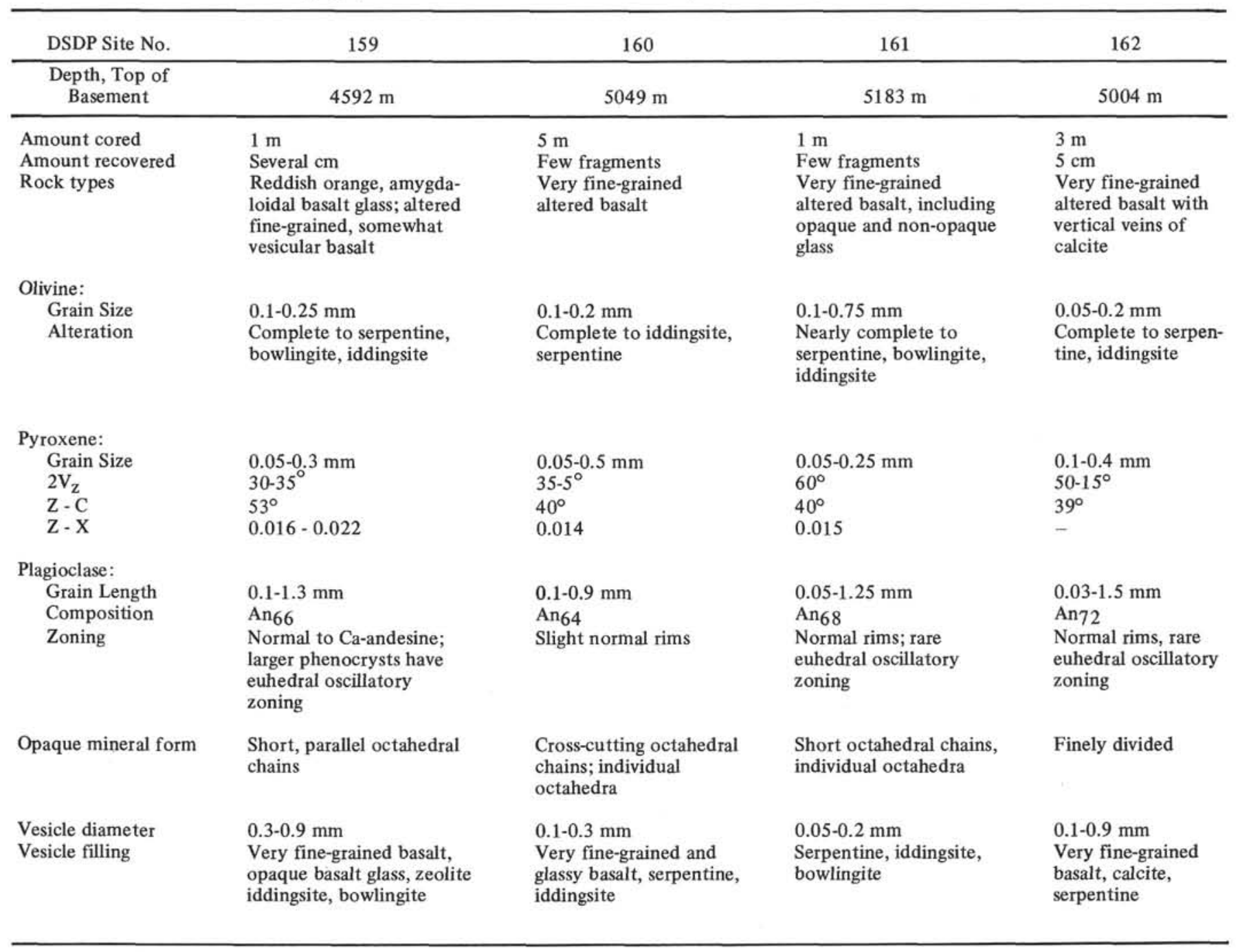

\section{MODE OF EMPLACEMENT}

At all sites the sediments immediately overlying basement show no effect of metamorphism by the basalt. At DSDP 157, 159, 161, and 163, glass was found at the sediment-basalt contact. It has been assumed, therefore, that the basalt is extrusive at all sites.

A limestone xenolith in basalt at DSDP 155 indicates that basalt extrusion postdated the deposition of some carbonate sediments there. The limestone is recrystallized and contains no fossils, in contrast with the sediments immediately overlying the basalt. The silicified crusts of basalt at DSDP 157 suggest metasomatic reaction between the basalt and overlying chert-bearing sediments, but this may have occurred long after extrusive emplacement.

At DSDP 163, where core recovery was relatively complete, the $15^{\circ}-70^{\circ}$ dips of sideromelane glass boundaries between many of the cooling units suggest pillow structure. No intrusive contacts were observed.

\section{MINERAL CHEMISTRY}

Quantitative analyses of pyroxene, olivine, plagioclase, and opaque minerals were made by electron probe using polished thin sections of specimens 157-49-2(55-65), 157 49-2(146-148), 158-36(CC), 159-BIT, 160-13(CC), and 163-29-4(67). Standards for pyroxene consisted of wetchemically analyzed minerals. Dunka River hedenburgite (Bonnichsen, 1969) was used for $\mathrm{Ca}, \mathrm{Mg}, \mathrm{Fe}, \mathrm{Si}$, grossularite for $\mathrm{Al}$, and cossyrite (Zies, 1966) for Ti and Mn. A synthetic anorthite- 50 glass was used for the plagioclase analyses.

\section{Pyroxene}

Analyses of pyroxenes from the rocks listed above are given in Table 5 and are plotted in Figure 19 in terms of atomic per cent Wo, En, and Fs. In three samples, two analyses are given, partially indicating grain-to-grain variability. The pyroxenes range in composition from typical augite to subcalcic augite and resemble the trend of pyroxene compositions of the Mid-Atlantic Ridge (Muir and Tilley, 1964). Like these pyroxenes, the 157-49-2(55-65), 159-BIT, and 163-29-4(67) specimens are notable for their high $\mathrm{Al}$ contents. The abundance of $\mathrm{Al}$ in the pyroxene is apparently unrelated to changes in other components and may simply reflect conditions of crystallization and peculiarities in the bulk composition of the liquid. Simi- 


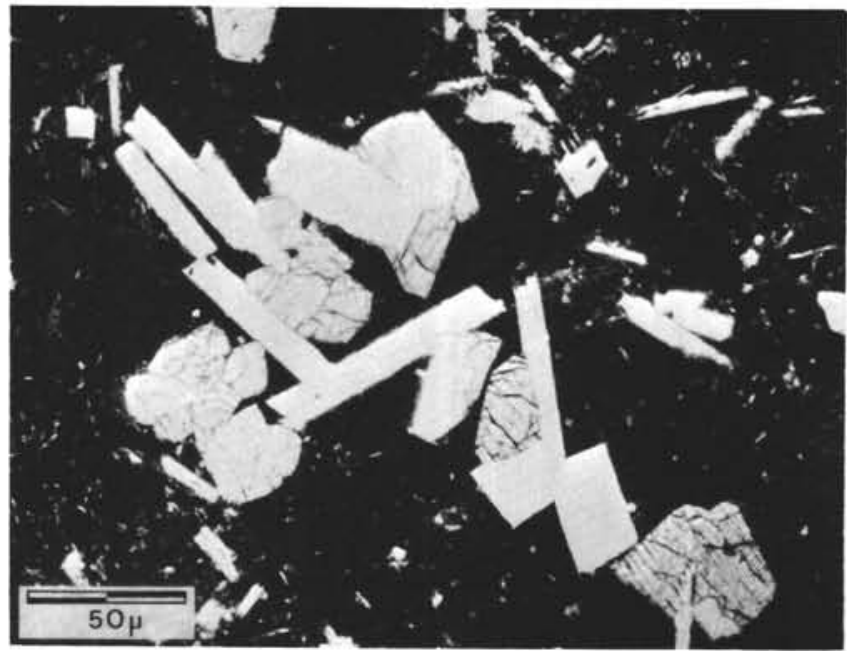

Figure 13. Core catcher sample, Core 13, DSDP 160, west flank of the East Pacific Rise. Fine-grained basalt with opaque glassy matrix. Euhedral, pre-emplacement phenocrysts and phenocryst clusters of labradorite and augite. Euhedral augite is in contrast to anhedral, late-formed augite in other basalts from the East Pacific Rise flank. Plane polarized light.

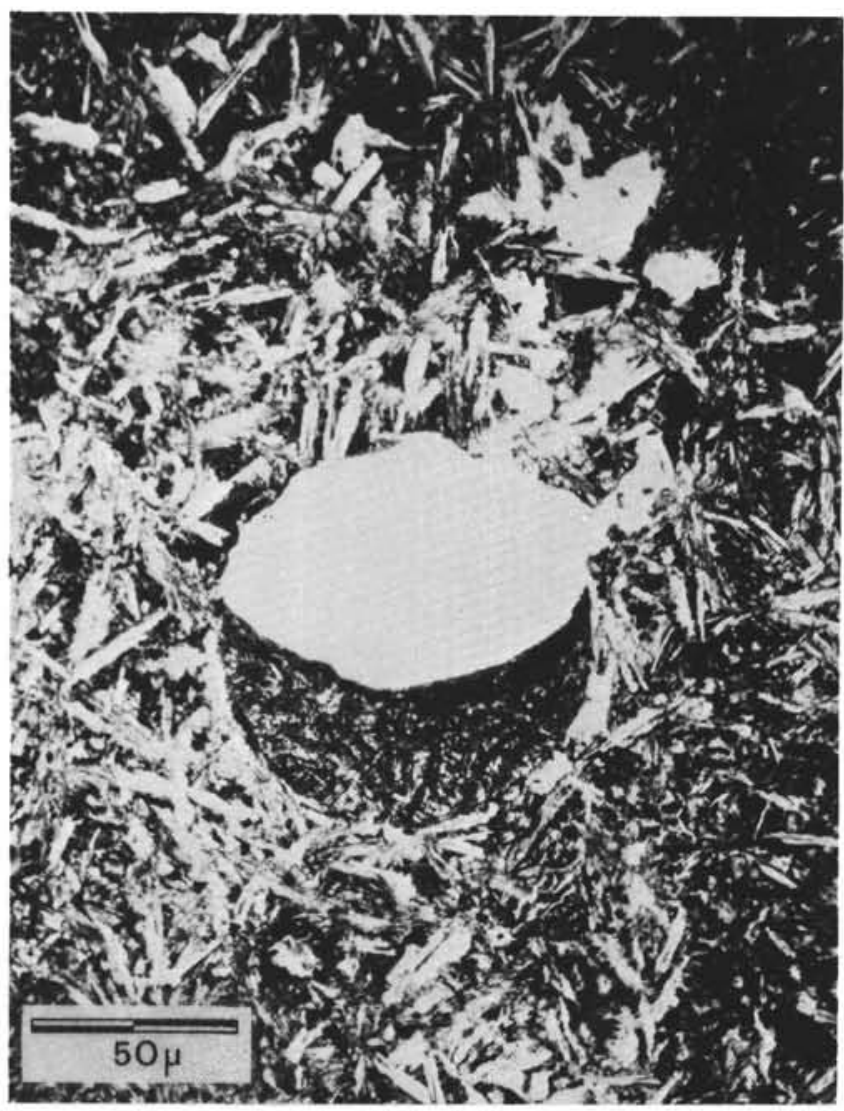

Figure 14. Bit sample, DSDP 159, west flank of the East Pacific Rise. Vesicle partially filled with glassy basalt containing microlites of plagioclase and short octahedral chains of opaque minerals. Plane polarized light.
TABLE 4

Petrography of Basement Rocks at DSDP 155,157 , and 158 , Panama Basin

\begin{tabular}{|c|c|c|c|}
\hline $\begin{array}{c}\text { DSDP } \\
\text { Site No. }\end{array}$ & 155 & 157 & 158 \\
\hline $\begin{array}{l}\text { Depth, top of } \\
\text { basement }\end{array}$ & $3271 \mathrm{~m}$ & $3022 \mathrm{~m}$ & $2276 \mathrm{~m}$ \\
\hline Amount cored & $17 \mathrm{~m}$ & $6 \mathrm{~m}$ & $1 \mathrm{~m}$ \\
\hline $\begin{array}{l}\text { Amount } \\
\text { recovered }\end{array}$ & about $1.3 \mathrm{~m}$ & $1.9 \mathrm{~m}$ & few centimeters \\
\hline Rock types & $\begin{array}{l}\text { Highly altered } \\
\text { holocrystalline } \\
\text { basalt and } \\
\text { devitrified } \\
\text { basalt; lime- } \\
\text { stone xenolith } \\
\text { in basalt }\end{array}$ & $\begin{array}{l}\text { Silicified } \\
\text { crusts of } \\
\text { amygdaloidal } \\
\text { glassy basalt; } \\
\text { very fine- } \\
\text { grained } \\
\text { porphyritic } \\
\text { basalt }\end{array}$ & $\begin{array}{l}\text { Fine-grained, } \\
\text { massive altered } \\
\text { basalt }\end{array}$ \\
\hline \multicolumn{4}{|l|}{ Olivine: } \\
\hline Grain size & $0.05-0.3 \mathrm{~mm}$ & $0.03-0.5 \mathrm{~mm}$ & None found \\
\hline Alteration & $\begin{array}{l}\text { Complete to } \\
\text { serpentine }\end{array}$ & $\begin{array}{l}\text { Complete to } \\
\text { serpentine }\end{array}$ & \\
\hline \multicolumn{4}{|l|}{ Pyroxene: } \\
\hline Grain size & $0.2-2.5 \mathrm{~mm}$ & $0.1-0.8 \mathrm{~mm}$ & $0.05-0.25 \mathrm{~mm}$ \\
\hline $2 \mathrm{~V}_{\mathrm{z}}$ & $40-45$ & & \\
\hline $2 \mathrm{C}$ & 54 & 38 & \\
\hline $\mathrm{Z}-\mathrm{X}$ & 0.015 & $0.015-0.019$ & 0.014 \\
\hline \multicolumn{4}{|l|}{ Plagioclase: } \\
\hline Grain length & $0.2-1.7 \mathrm{~mm}$ & $0.1-4 \mathrm{~mm}$ & $0.1-1.0$ \\
\hline Composition & $\mathrm{An}_{62}$ & $\mathrm{An}_{69-73}$ & $\mathrm{An}_{58}$ \\
\hline Zoning & $\begin{array}{l}\text { Normally } \\
\text { zoned to } \mathrm{An}_{33}\end{array}$ & $\begin{array}{l}\text { Normal rims } \\
\text { to An } 37 \text {; many } \\
\text { faint euhedral } \\
\text { oscillatory } \\
\text { zones in } \\
\text { larger } \\
\text { phenocrysts }\end{array}$ & Normally zoned \\
\hline $\begin{array}{l}\text { Opaque } \\
\text { mineral }\end{array}$ & $\begin{array}{l}\text { Octahedral } \\
\text { chains } \\
\text { possible } \\
\text { prisms; pyrite } \\
\text { cubes }\end{array}$ & $\begin{array}{l}\text { Octahedra, } \\
\text { skeletal } \\
\text { octahedra, } \\
\text { octahedral } \\
\text { chains }\end{array}$ & $\begin{array}{l}\text { Skeletal } \\
\text { octahedra, } \\
\text { octahedral chains }\end{array}$ \\
\hline $\begin{array}{l}\text { Vesicle } \\
\text { diameter }\end{array}$ & $0.4-2 \mathrm{~mm}$ & $0.05-3 \mathrm{~mm}$ & $0.7-1.5 \mathrm{~mm}$ \\
\hline Vesicle filling & $\begin{array}{l}\text { Calcite } \\
\text { rimmed } \\
\text { with } \\
\text { serpentine }\end{array}$ & $\begin{array}{l}\text { Chalcedonic } \\
\text { quartz }\end{array}$ & $\begin{array}{l}\text { Very fine- } \\
\text { grained basalt, } \\
\text { serpentine, } \\
\text { zeolite }\end{array}$ \\
\hline
\end{tabular}

larly, the abundance of $\mathrm{TiO}_{2}$ changes by a factor of four. Because the rock bulk compositions do not show corresponding changes in titanium, the variation must be attributable to local crystallization conditions. This is clearly seen in analyses 157-49-2(55-65) and 157-492(146-148), both of pyroxenes from the same cooling unit of essentially constant composition. There is approximately a two-fold variation in $\mathrm{TiO}_{2}$ and $\mathrm{Al}_{2} \mathrm{O}_{3}$ in the pyroxenes.

Pyroxene containing substantial amounts of sodium (occupying up to 14 per cent of the Ca positions) was found only in the 163-29-4(67) sample. The pyroxenes in this rock show considerable grain-to-grain variation, and a consistent decrease in $\mathrm{Na}$ with iron enrichment. 


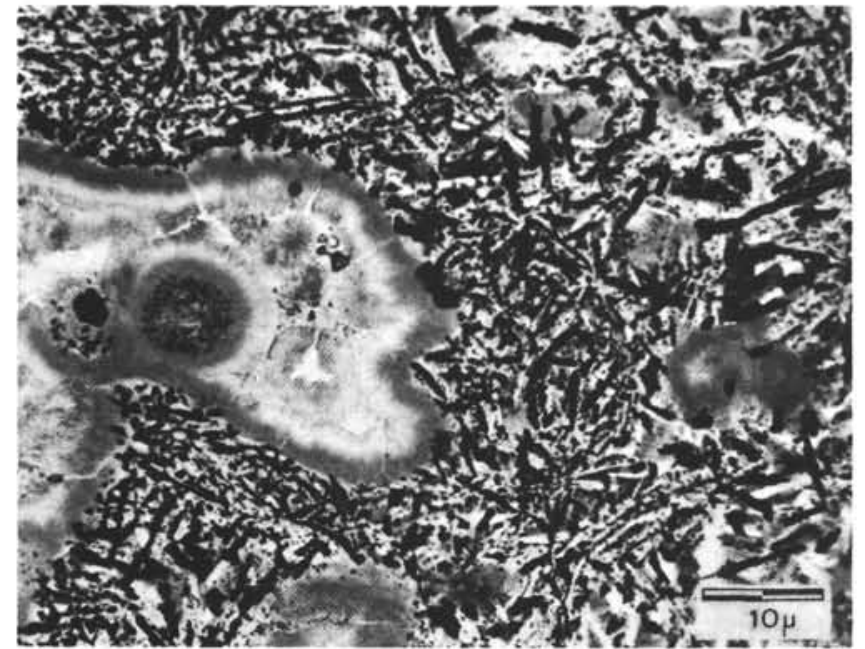

Figure 15. Core 36 catcher sample, DSDP 158, Cocos Ridge. Fine-grained altered basalt with octahedral chains of spinellid opaque minerals and vesicles (?) filled with serpentine. Plane polarized light.

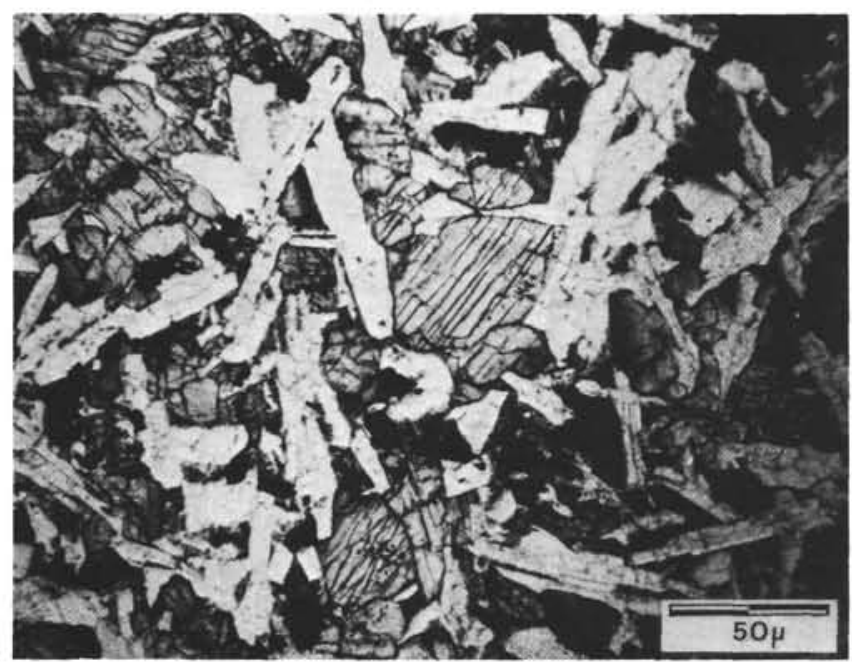

Figure 16. Sample DSDP 157-49-2(148), Carnegie Ridge. Holocrystalline basalt with diabasic texture. Labradorite and interstitial augite quite fresh.

The manganese content of these pyroxenes, with the exception of $160-13(\mathrm{CC})$, is remarkably constant. The variations found may be within experimental error. Approximately 0.02 weight per cent $\mathrm{Cr}_{2} \mathrm{O}_{3}$ was found in variolitic pyroxene from 163-29-4(67). With this exception, no other transition metals were detected in the pyroxenes. Limits of detectability for $\mathrm{V}, \mathrm{Cr}, \mathrm{Co}, \mathrm{Ni}, \mathrm{Cu}$, and $\mathrm{Zn}$ are estimated to be about 0.01 weight per cent of the oxide.

Many of the pyroxene grains studied consist of several compositional domains. The compositional domains were first recognized because of variations in such optical properties as birefringence and extinction (Figure 17). Zoning of birefringence consists of anhedral, more highly birefringent cores with relatively sharp zone boundaries. Zoning of extinction is manifested by undulatory or incomplete extinction and, locally, by hourglass structure. Variation in absorption is also noted. In many cases, the compositional variation is complicated by incipient exsolution of

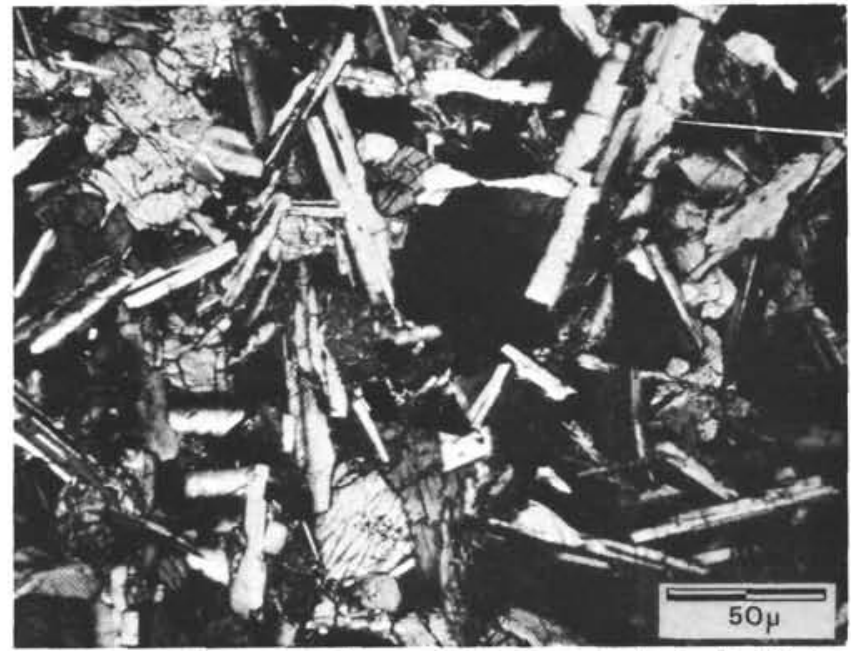

Figure 17. As shown Figure 16, but crossed nicols. Variable extinction shown by pyroxene in upper left corner is controlled by variations in composition, based on electron microprobe analysis.

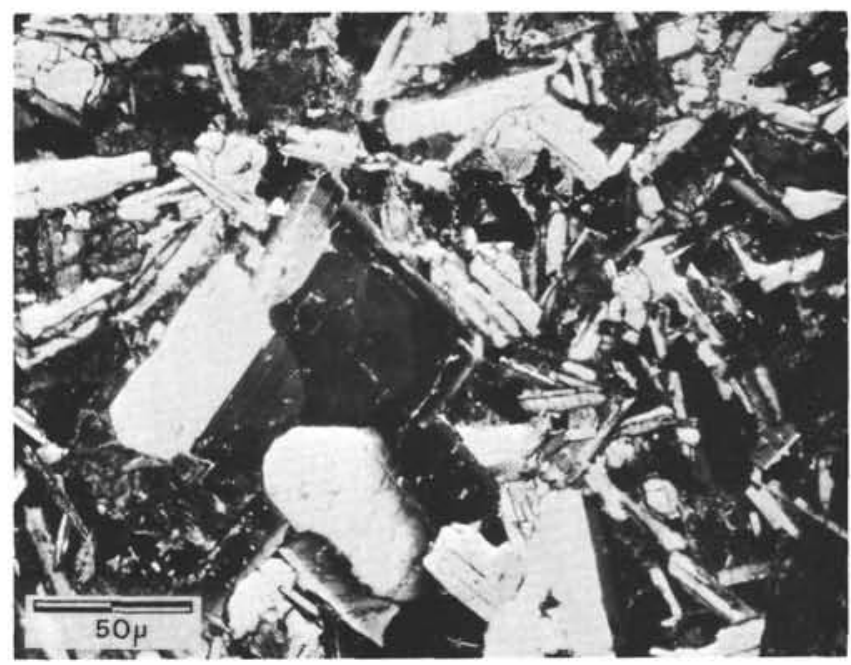

Figure 18. Sample DSDP 157-49-2(148), Carnegie Ridge. Glomeroporphyritic cluster of plagioclase showing euhedraloscillatory zoning and synneusis. Plagioclase is calcic labradorite with rims as sodic as andesine.

orthopyroxene or pigeonite. Nine of these domains, recognizable optically, were analyzed in a pyroxene from 157 . 49-2(55-65), with the results presented in Table 6 and Figure 20. These analyses may be conveniently divided into only two groups on the basis of their Ca content. In a Ca-Mg-Fe ternary diagram, analyses 2, 3, and 7 (Group I) have $\mathrm{Ca}$ values of $42-43$ atomic per cent, whereas analyses 1, 4, 5, 6, 8, and 9 (Group II) have Ca values of 37-39 atomic per cent. The difference between Group I and II is small but is probably real. No other systematic compositional differences between these groups are apparent. However, the intracrystalline variability of $\mathrm{TiO}_{2}, \mathrm{Al}$, $\mathrm{O}_{3}$, and $\mathrm{Na}_{2} \mathrm{O}$ is notable. Adjacent domains such as 5 and 8 have 2.5 -fold differences in $\mathrm{TiO}_{2}$ and other large differences in $\mathrm{FeO}, \mathrm{CaO}$, and $\mathrm{Na}_{2} \mathrm{O}$. Similarly, different sectors are marked by a twofold difference in $\mathrm{A}_{2} \mathrm{O}_{3}$. A major variation is also shown by $\mathrm{Na}_{2} \mathrm{O}$. It is present in less than 
TABLE 5

Electron Microprobe Analyses of Pyroxene Crystals in Basalts from DSDP 157, 159, 160, and 163

\begin{tabular}{|c|c|c|c|c|c|c|c|c|}
\hline & I & II & IIa & III & IV & IVa & V & Va \\
\hline $\mathrm{SiO}_{2}$ & 51.2 & 51.4 & 53.5 & 47.5 & 50.4 & 51.7 & 50.5 & 50.0 \\
\hline $\mathrm{TiO}_{2}$ & 0.94 & 0.51 & 0.62 & 2.11 & 1.00 & 1.12 & 1.16 & 2.14 \\
\hline $\mathrm{Al}_{2} \mathrm{O}_{3}$ & 4.18 & 2.46 & 2.42 & 4.89 & 3.00 & 2.85 & 4.30 & 3.42 \\
\hline $\mathrm{FeO}$ & 7.13 & 7.52 & 7.67 & 9.99 & 10.85 & 9.94 & 7.55 & 14.5 \\
\hline $\mathrm{MnO}$ & 0.23 & 0.23 & 0.24 & 0.31 & $\mathrm{tr}$ & $\operatorname{tr}$ & 0.17 & 0.34 \\
\hline $\mathrm{MgO}$ & 16.41 & 15.3 & 17.7 & 15.4 & 17.7 & 15.8 & 16.9 & 12.3 \\
\hline $\mathrm{CaO}$ & 20.5 & 21.4 & 19.0 & 18.5 & 17.4 & 19.2 & 20.3 & 17.3 \\
\hline $\mathrm{Na}_{2} \mathrm{O}$ & $<0.03$ & 0.03 & $<0.03$ & $<0.03$ & $<0.03$ & $<0.03$ & 1.99 & 0.22 \\
\hline $\mathrm{K}_{2} \mathrm{O}$ & $<0.02$ & $<0.02$ & $<0.02$ & $<0.02$ & $<0.02$ & $<0.02$ & $<0.02$ & $<0.02$ \\
\hline Total & 100.56 & 98.97 & 101.16 & 98.66 & 100.35 & 100.64 & 102.9 & 100.23 \\
\hline \multicolumn{9}{|c|}{ Numbers of cations on the basis of $6(0)$} \\
\hline $\mathrm{Si}$ & 1.88 & 1.92 & 1.94 & 1.80 & 1.87 & 1.91 & 1.83 & 1.89 \\
\hline $\mathrm{Al}$ & 0.12 & 0.08 & 0.06 & 0.20 & 0.13 & 0.09 & 0.17 & 0.11 \\
\hline Al & 0.06 & 0.03 & 0.04 & 0.02 & - & 0.03 & 0.01 & 0.04 \\
\hline $\mathrm{Ti}$ & 0.03 & 0.01 & 0.02 & 0.06 & 0.03 & 0.03 & 0.03 & 0.06 \\
\hline $\mathrm{Fe}$ & 0.22 & 0.24 & 0.23 & 0.32 & 0.34 & 0.31 & 0.23 & 0.46 \\
\hline $\mathrm{Mn}$ & 0.01 & 0.01 & 0.01 & 0.01 & - & - & 0.01 & 0.01 \\
\hline $\mathrm{Mg}$ & 0.90 & 0.85 & 0.96 & 0.87 & 0.98 & 0.87 & 0.91 & 0.69 \\
\hline $\mathrm{Ca}$ & 0.80 & 0.86 & 0.74 & 0.75 & 0.69 & 0.76 & 0.78 & 0.70 \\
\hline $\mathrm{Na}$ & - & 0.02 & - & - & - & - & 0.14 & 0.02 \\
\hline K & - & - & - & - & - & - & - & - \\
\hline $\mathrm{X}$ & 0.80 & 0.88 & 0.74 & 0.75 & 0.69 & 0.76 & 0.92 & 0.72 \\
\hline $\mathrm{Y}$ & 1.22 & 1.14 & 1.26 & 1.28 & 1.35 & 1.24 & 1.19 & 1.26 \\
\hline$X \& Y$ & 2.02 & 2.02 & 2.00 & 2.03 & 2.04 & 2.00 & 2.11 & 1.98 \\
\hline \multicolumn{9}{|c|}{ Atomic \% } \\
\hline $\mathrm{Ca}$ & 42 & 44 & 38 & 39 & 34 & 39 & 41 & 38 \\
\hline $\mathrm{Mg}$ & 47 & 44 & 50 & 45 & 49 & 45 & 47 & 37 \\
\hline $\mathrm{Fe}$ & 11 & 12 & 12 & 16 & 17 & 16 & 12 & 25 \\
\hline $\begin{array}{l}\text { I } \\
\text { II, IIa } \\
\text { III } \\
\text { IV, IVa } \\
\text { V, Va }\end{array}$ & \multicolumn{8}{|c|}{$\begin{array}{l}=157-49-2(55-65) \\
=157-49-2(146-148), \text { two grains. } \\
=159(\mathrm{BIT}), \text { average of three grains. } \\
=160-13(\mathrm{CC}), \text { small grain in groundmass. } \\
=163-29-4(67), \text { large equent grain. }\end{array}$} \\
\hline
\end{tabular}

detectable amounts in domains 3 and 4 , whereas domain 8 contains 0.57 weight per cent. The variation in the major components is considerably less than that shown by the minor elements. Thus, variations in the optical properties of these pyroxenes (Figure 17) are probably attributable to variations in the abundance of $\mathrm{Al}_{2} \mathrm{O}_{3}, \mathrm{TiO}_{2}$, and $\mathrm{Na}_{2} \mathrm{O}$. The composition of each domain is almost constant, whereas the domain boundary is marked by an abrupt change in the abundance of one or more components over a 1-to3-micron distance. This "domain" character is typical of lunar pyroxenes and may represent a quench phenomenon.

The oceanic basalt pyroxenes also exhibit a second type of compositional variation caused by a progressive change in the Wo/En/Fs values. This is most pronounced in
163-29-4(67) from the felty-textured core of cooling unit 6. Within a single grain the Fs content changes from 12 to 35 atomic per cent as the edge of the grain is approached. The change in $\mathrm{Ca}: \mathrm{Mg}: \mathrm{Fe}$ values within a single grain is shown in Figure 19, where V represents the analysis of the core of the grain and VI is the analysis of the edge. The compositional variation is also defined by a progressive change in the extinction angle of these grains. It is believed that this type of zoning represents crystallization from a magma that is rapidly changing in composition. This condition would be met by crystallization from the margin inward in a large pillow. The corresponding increases in $\mathrm{TiO}_{2}$ and $\mathrm{MnO}$ (Table 5, $\mathrm{V}$ and $\mathrm{Va}$ ) suggest that residual basaltic liquids are enriched in these components in at least some crystallization environments. This 
TABLE 6

Compositional Domains in Pynoxene from 157-49-2(55-65)

\begin{tabular}{|c|c|c|c|c|c|c|c|c|c|}
\hline & 1 & 2 & 3 & 4 & 5 & 6 & 7 & 8 & 9 \\
\hline $\mathrm{SiO}_{2}$ & 50.6 & 53.6 & 50.0 & 53.0 & 48.4 & 54.8 & 51.9 & 53.2 & 52.5 \\
\hline $\mathrm{TiO}_{2}$ & 1.04 & 0.75 & 0.91 & 1.16 & 1.46 & 0.57 & 1.13 & 0.56 & 0.76 \\
\hline $\mathrm{Al}_{2} \mathrm{O}_{3}$ & 3.95 & 4.08 & 3.32 & 2.01 & 2.55 & 1.55 & 4.21 & 1.76 & 3.57 \\
\hline $\mathrm{FeO}$ & 7.70 & 7.01 & 6.36 & 7.78 & 9.15 & 8.40 & 7.23 & 6.99 & 8.07 \\
\hline $\mathrm{MnO}$ & 0.24 & 0.22 & 0.24 & 0.22 & 0.28 & 0.23 & 0.23 & 0.21 & 0.16 \\
\hline $\mathrm{MgO}$ & 18.5 & 15.4 & 15.4 & 17.6 & 18.3 & 16.5 & 14.9 & 17.5 & 16.3 \\
\hline $\mathrm{CaO}$ & 18.9 & 19.7 & 19.4 & 19.5 & 19.4 & 18.1 & 19.9 & 18.6 & 18.2 \\
\hline $\mathrm{Na}_{2} \mathrm{O}$ & 0.20 & 0.34 & - & - & 0.18 & 0.14 & 0.06 & 0.57 & 0.03 \\
\hline $\mathrm{K}_{2} \mathrm{O}$ & 0.05 & 0.05 & 0.06 & 0.04 & 0.05 & 0.06 & 0.05 & 0.05 & 0.05 \\
\hline Total & 101.12 & 101.10 & 95.64 & 101.31 & 99.76 & 100.41 & 99.57 & 99.42 & 99.56 \\
\hline \multicolumn{10}{|c|}{ Numbers of cations on the basis of $6(0)$} \\
\hline $\mathrm{Si}$ & 1.85 & 1.94 & 1.92 & 1.93 & 1.82 & 2.00 & 1.91 & 1.96 & 1.93 \\
\hline $\mathrm{Al}$ & 0.15 & 0.06 & 0.08 & 0.07 & 0.11 & - & 0.09 & 0.04 & 0.07 \\
\hline $\mathrm{Al}$ & 0.02 & 0.11 & 0.07 & 0.02 & - & 0.07 & 0.09 & 0.04 & 0.09 \\
\hline $\mathrm{Ti}$ & 0.03 & 0.03 & 0.03 & 0.03 & 0.04 & 0.02 & 0.03 & 0.02 & 0.02 \\
\hline $\mathrm{Fe}$ & 0.24 & 0.21 & 0.20 & 0.24 & 0.29 & 0.26 & 0.22 & 0.22 & 0.25 \\
\hline $\mathrm{Mn}$ & 0.01 & 0.01 & 0.01 & 0.01 & 0.01 & 0.01 & 0.01 & 0.01 & 0.01 \\
\hline $\mathrm{Mg}$ & 1.00 & 0.83 & 0.88 & 0.95 & 1.02 & 0.90 & 0.82 & 0.96 & 0.89 \\
\hline $\mathrm{Ca}$ & 0.74 & 0.76 & 0.80 & 0.76 & 0.78 & 0.71 & 0.78 & 0.73 & 0.72 \\
\hline $\mathrm{Na}>$ & 0.01 & 0.024 & - & - & 0.013 & 0.01 & 0.004 & 0.04 & 0.002 \\
\hline K & 0 & 0.002 & 0.003 & 0.002 & 0.002 & 0.003 & 0.002 & 0.002 & 0.002 \\
\hline$X$ & 0.75 & 0.78 & 0.80 & 0.76 & 0.79 & 0.72 & 0.79 & 0.77 & 0.72 \\
\hline $\mathbf{Y}$ & 1.30 & 1.19 & 1.19 & 1.25 & 1.32 & 1.26 & 1.17 & 1.25 & 1.26 \\
\hline$X \& Y$ & 2.05 & 1.97 & 1.99 & 2.01 & 2.06 & 1.98 & 1.96 & 2.02 & 1.98 \\
\hline \multicolumn{10}{|c|}{ Atomic $\%$} \\
\hline $\mathrm{Ca}$ & 37 & 42 & 43 & 39 & 37 & 38 & 43 & 38 & 39 \\
\hline $\mathrm{Mg}$ & 50 & 46 & 47 & 49 & 49 & 48 & 45 & 50 & 48 \\
\hline $\mathrm{Fe}$ & 13 & 12 & 10 & 12 & 14 & 14 & 12 & 12 & 13 \\
\hline
\end{tabular}

analysis can be contrasted to pyroxene from 157-49-2(146148) where a depletion in $\mathrm{TiO}_{2}$ was found in the grain margins.

In the larger clinopyroxene grains of 160-13-(CC), there are areas of what appear to be incipient exsolution of a Ca-poor phase. The Wo content is approximately 25-30 per cent, while the En and Fs contents are correspondingly higher. These areas are not optically noticeable and are less than 10 square microns in area. Both their shapes and distributions about the grains are irregular.

\section{Olivine}

Of the samples analyzed, olivine was found only in 163-29-4(67). In this sample, olivine occurs as microphenocrysts with composition ranging from $\mathrm{Fo}_{87-85}$. This agrees well with the composition determined optically using $2 \mathrm{~V}$ (Table 2 ). The grains are very slightly zoned with iron enrichment toward the grain edges. The groundmass olivine is more iron-rich and has a composition of
$\mathrm{Fo}_{80}$. These iron contents are comparable to olivine compositions of tholeiitic-type basalts reported by Muir and Tilley (1964).

The olivines contain 0.25 per cent $\mathrm{MnO}$ and 0.06-0.09 per cent $\mathrm{TiO}_{2}$. No other elements were detected.

\section{Plagioclase}

The plagioclases of the oceanic basalts show rather systematic compositional changes as a function of grain size within a given rock, as well as intragranular variation. The zoning in most of the plagioclase phenocrysts is marked both optically and chemically, and there are large changes in the anorthite content in the marginal portions. Plagioclase analyses are given in Table 7 with the observed range in anorthite content shown at the bottom. Optical determinations using extinction angle and $2 \mathrm{~V}$ and chemical analysis show that the plagioclase phenocrysts have an average An content of approximately 65 which is considerably more calcic than normal tholeiitic plagioclase $\left(\mathrm{An}_{55}\right)$ 


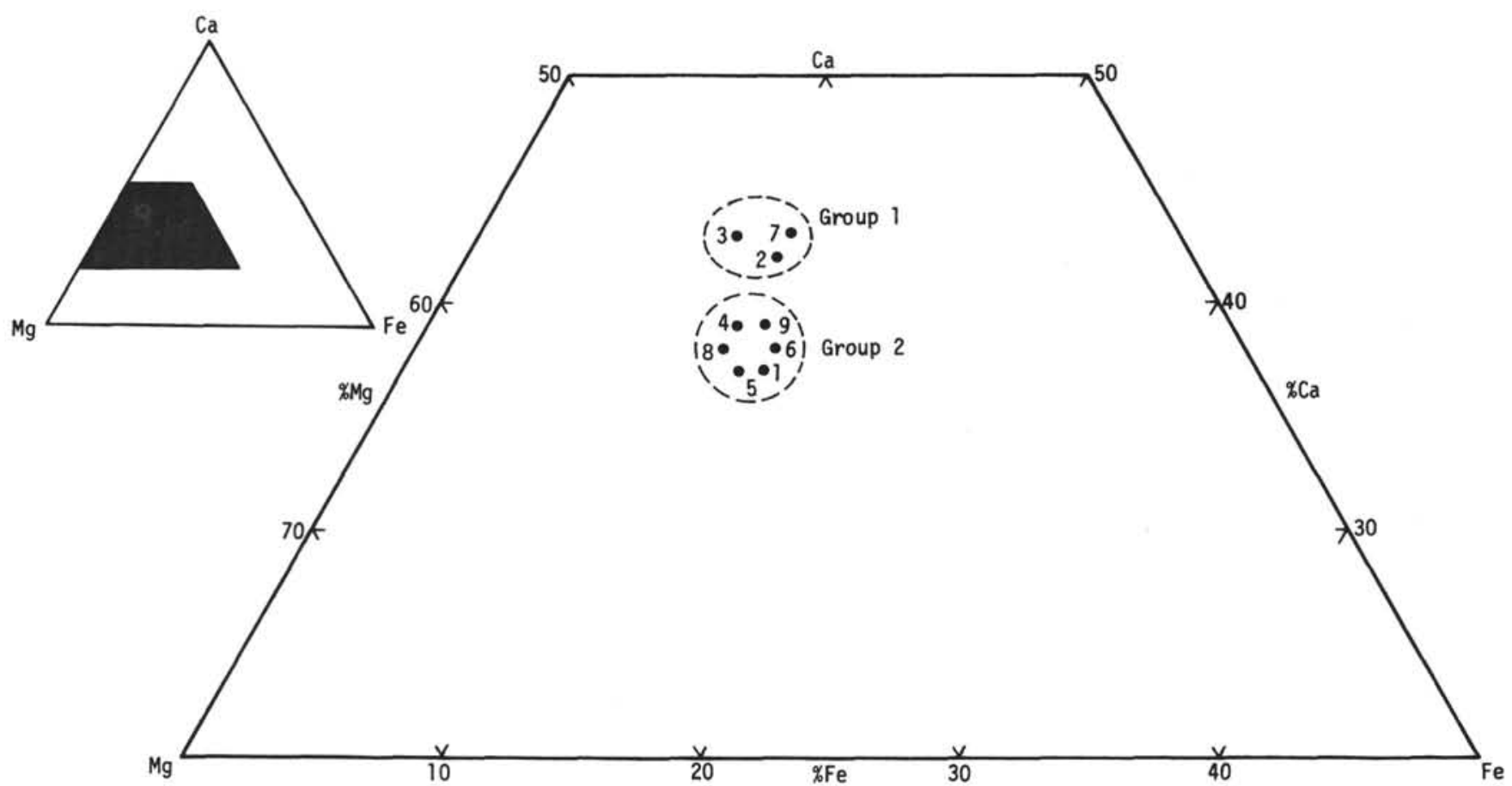

Figure 19. Electron microprobe analyses of pyroxene grains from DSDP 157,159, 160, and 163 in terms of atomic per cents $\mathrm{Ca}, \mathrm{Mg}$, and $\mathrm{Fe}$. See Table 5 for sample identification.

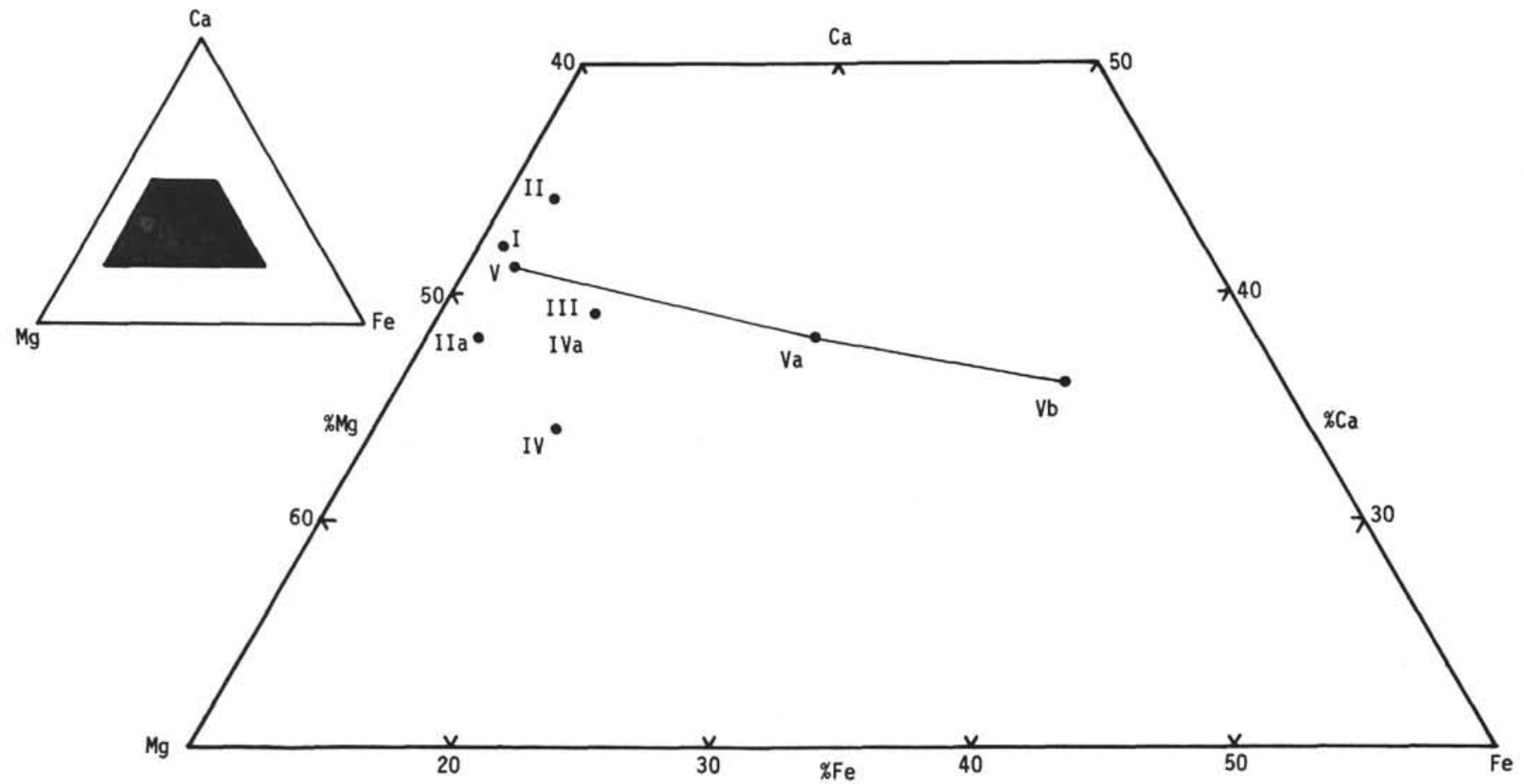

Figure 20. Compositional domains in pyroxene from 157-49-2(55-65) in terms of atomic per cents Ca, Mg, and Fe. See Table 6 for analyses.

but is less calcic than phenocrysts associated with basalt glass from the crests of mid-ocean ridges (Scheidegger, 1972). Extremes are found in 157-49-2(55-65), $\mathrm{An}=79$, and 163-29-4(67), An=48. It may be noted that the DSDP 163 basalt contains the most iron-rich pyroxene found (see above) and may represent a strongly differentiated unit. The large plagioclase grains commonly show oscillatory zoning, but the An-variation through the bulk of the crystal is never more than a few per cent. In con- trast, eleven plagioclase grains analyzed show a marked sodium enrichment at the edges. This enrichment zone ranges from 4 to 15 microns in width and has an An range of 30-40. If the rock contains plagioclase of several grain sizes, the smaller laths invariably are more sodic. This reflects previously observed compositional changes in plagioclase in differentiated basic rocks.

Iron is a persistent constituent of plagioclase. $\mathrm{Fe}$ was determined as $\mathrm{FeO}$ and recalculated as $\mathrm{Fe}_{2} \mathrm{O}_{3}$ in the anal- 
TABLE 7

Electron Microprobe Analyses of Plagioclase Crystals in Basalts from DSDP $157,158,160$, and 163

\begin{tabular}{lcccccc}
\hline & $\begin{array}{c}157-49-2 \\
(55-65)^{\mathrm{a}}\end{array}$ & $\begin{array}{c}157-49-2 \\
(146-148)^{\mathrm{a}}\end{array}$ & $\begin{array}{c}158-36 \\
(\mathrm{CC})^{\mathrm{b}}\end{array}$ & $\begin{array}{c}159 \\
(\mathrm{BIT})^{\mathrm{c}}\end{array}$ & $\begin{array}{c}160-13 \\
(\mathrm{CC})^{\mathrm{d}}\end{array}$ & $\begin{array}{c}163-29-4 \\
(67)^{\mathrm{e}}\end{array}$ \\
\hline $\mathrm{SiO}_{2}$ & 46.1 & 53.2 & 51.9 & 54.5 & 55.7 & 51.5 \\
$\mathrm{Al}_{2} \mathrm{O}_{3}$ & 31.5 & 29.3 & 30.0 & 29.2 & 27.4 & 29.3 \\
$\mathrm{Fe}_{2} \mathrm{O}_{3}$ & 0.56 & 0.64 & 1.19 & 0.50 & 0.79 & 1.11 \\
$\mathrm{CaO}$ & 16.6 & 13.0 & 13.0 & 13.6 & 11.7 & 10.9 \\
$\mathrm{Na}_{2} \mathrm{O}$ & 2.4 & 3.9 & 4.0 & 3.7 & 4.4 & 5.9 \\
& 97.07 & 99.92 & 100.11 & 101.52 & 99.96 & 98.57 \\
\hline
\end{tabular}

Numbers of Ions on the basis of $8(0)$

\begin{tabular}{lllllll}
\hline $\mathrm{Si}$ & 2.19 & 2.41 & 2.37 & 2.43 & 2.51 & 2.38 \\
$\mathrm{Al}$ & 1.76 & 1.57 & 1.61 & 1.54 & 1.46 & 1.60 \\
$\mathrm{Fe}$ & 0.02 & 0.02 & 0.04 & 0.02 & 0.03 & 0.04 \\
$\mathrm{Ca}$ & 0.84 & 0.63 & 0.63 & 0.65 & 0.57 & 0.54 \\
$\mathrm{Na}$ & 0.22 & 0.34 & 0.35 & 0.32 & 0.38 & 0.53 \\
$\mathrm{An}$ & $79-75$ & $65-60$ & $64-53$ & $68-42$ & $60-58$ & $50-45$ \\
\hline
\end{tabular}

${ }^{\mathrm{a}}$ Cores of large laths

${ }^{\mathrm{b}}$ Core of phenocryst

${ }^{\mathrm{c}}$ Large plagioclase grain

$\mathrm{d}_{\text {Medium-sized lath }}$

${ }^{\mathrm{e}}$ Core of lath

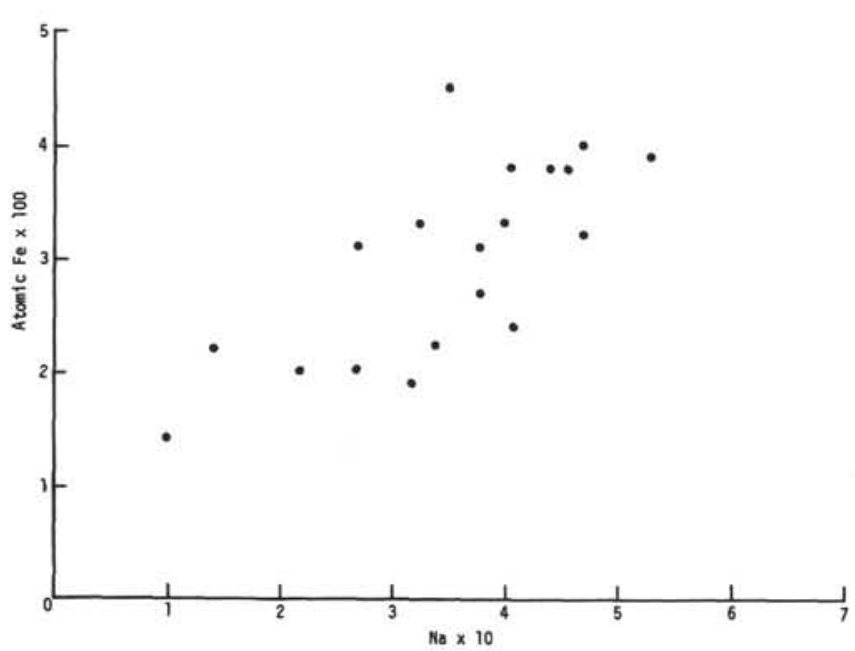

Figure 21. Relationship between numbers of $\mathrm{Na}$ and $\mathrm{Fe}$ ions per plagioclase unit cell in DSDP 157, 158,160, and 163 basalts. See Table 7 for partial list of data.

ysis. The relationship between the number of iron and sodium (albite) ions per formula unit is shown in Figure 21 . The correlation coefficient between these parameters is 0.74 , which is significant for the number of samples analyzed. The preliminary data suggest the presence of an $\mathrm{NaFe}^{+3} \mathrm{Si}_{3} \mathrm{O}_{8}$ component in these plagioclases. Plagioclase analyses published by Deer et al. (1963) do not show a correlation between $\mathrm{Na}$ and $\mathrm{Fe}^{+3}$ contents in terrestrial plagioclases. Thus, additional compositional data on plagioclases from deep-sea basalts are required before the $\mathrm{NaFe}^{+3} \mathrm{Si}_{3} \mathrm{O}_{8}$ component is confirmed.
TABLE 8

Electron Microprobe Analy ses of Opaque Minerals in Basalts from DSDP 157 and 163

\begin{tabular}{|c|c|c|c|c|c|c|c|}
\hline \multicolumn{4}{|c|}{$157-49-2(146-148)$} & \multicolumn{4}{|c|}{$163-29-4(67)$} \\
\hline \multicolumn{2}{|c|}{ Element } & \multicolumn{2}{|c|}{ Oxide } & \multicolumn{2}{|c|}{ Element } & \multicolumn{2}{|c|}{ Oxide } \\
\hline $\mathrm{Ti}$ & 13.4 & $\mathrm{TiO}_{2}$ & 22.4 & $\mathrm{Ti}$ & 10.8 & $\mathrm{TiO}_{2}$ & 18.0 \\
\hline $\mathrm{Al}$ & 0.69 & $\mathrm{Al}_{2} \mathrm{O}_{3}$ & 1.30 & $\mathrm{Al}$ & 0.88 & $\mathrm{Al}_{2} \mathrm{O}_{3}$ & 1.66 \\
\hline \multirow[t]{2}{*}{$\mathrm{Fe}$} & 52.8 & $\mathrm{Fe}_{2} \mathrm{O}_{3}$ & 50.3 & $\mathrm{Fe}$ & 48.7 & $\mathrm{Fe}_{2} \mathrm{O}_{3}$ & 46.4 \\
\hline & & $\mathrm{FeO}$ & 22.6 & & & $\mathrm{FeO}$ & 20.9 \\
\hline Mn & 0.57 & $\mathrm{MnO}$ & 0.73 & Mn & 0.15 & $\mathrm{MnO}$ & 0.20 \\
\hline \multirow[t]{2}{*}{$\mathrm{Mg}$} & 0.31 & $\mathrm{MgO}$ & 0.52 & $\mathrm{Mg}$ & 1.16 & $\mathrm{MgO}$ & 1.92 \\
\hline & & & 97.85 & & & & 89.08 \\
\hline
\end{tabular}

No other elements were detected by complete spectrometer scans of the plagioclase specimens.

\section{Opaque Minerals}

Opaque minerals could be analyzed in only two thin sections. Exceedingly small grain size $(<10$ microns) precluded analytical work in the other polished specimens. The opaques analyzed are iron-titanium oxides containing minor amounts of $\mathrm{Al}, \mathrm{Mg}$, and $\mathrm{Mn}$. The full analyses are given in Table 8. One major problem with the electron microprobe is that it cannot distinguish trivalent and divalent iron. To determine the $\mathrm{Fe}^{+2} / \mathrm{Fe}^{+3}$ ratio in these opaques, the procedure outlined by Albee and Chodos (1970) was followed. This method uses the relative intensities of the $\mathrm{Fe} \mathrm{L}_{\alpha}$ and $\mathrm{L}_{\beta} \mathrm{X}$-ray emission peaks to determine the $\mathrm{Fe}^{+2} / \mathrm{Fe}^{+3}$ ratio semiquantitatively. By this technique, 
hematite can be distinquished from magnetite, for example. This method was applied to the DSDP 157 and 163 opaques. Using well-analyzed probe standards, the $\mathrm{FeL}_{\alpha} / \mathrm{L}_{\beta}$ intensity ratios were found to be 0.47 and 0.33 for magnetite and hematite respectively. The ratio for DSDP 157 was 0.42 and for DSDP $163,0.44$. This strongly suggests that the opaque is a magnetite, perhaps slightly more oxidized than the pure form. The influence of $\mathrm{Ti}$, which is present in substantial amounts, on the $\mathrm{L}_{\alpha} / \mathrm{L}_{\beta}$ ratios, is a severe complicating factor (Albee and Chodos, 1970). Sufficient material must be concentrated for X-ray diffraction work before the opaque type is firmly established. On the basis of the $\mathrm{L}_{\alpha} / \mathrm{L}_{\beta}$ results, the iron was apportioned in the ratio $2: 1\left(\mathrm{Fe}^{+3}: \mathrm{Fe}^{+2}\right)$ and the total oxide content calculated. The opaques, on this basis, may be termed titanomagnetites. The analysis totals are low. Repeated analyses using different standards and correction procedures have failed to raise the total. The DSDP 163 opaques are very small and the low total may be due to experimental error. This is not the case for DSDP 157, however, and the low oxide total may be attributable to hydration.

\section{GEOCHEMISTRY}

One sample each from DSDP 155 and 157-162 and six from DSDP 163 were analyzed by atomic absorption spectrophotometry at Oregon State University. Sample preparation follows the procedures described by Omang (1969). Preparation of standards and instrument settings are from Perkin-Elmer Analytical Methods Book. For accuracy, we compare thirteen analyses of USGS Standard BCR-1 done at Oregon State with twenty-nine analyses of this standard given by Flanagan (1969) (Table 9).

TABLE 9

Analy ses of USGS Standard BCR-1

\begin{tabular}{lcccc}
\hline & $\begin{array}{c}\text { Weight } \\
\text { Per Cent } \\
\text { Oregon State (Scheidegger) }\end{array}$ & $\begin{array}{c}\text { Standard } \\
\text { Deviation }\end{array}$ & $\begin{array}{c}\text { Weight } \\
\text { Per Cent } \\
\text { Flanagan }\end{array}$ & $\begin{array}{c}\text { Standard } \\
\text { Deviation }\end{array}$ \\
\hline $\mathrm{SiO}_{2}$ & 55.48 & 0.20 & 54.23 & 0.67 \\
$\mathrm{Al}_{2} \mathrm{O}_{3}$ & 13.33 & 0.24 & 13.56 & 0.46 \\
$\mathrm{Fe}_{2} \mathrm{O}_{3}$ & 13.18 & 0.20 & 13.57 & 0.30 \\
$\mathrm{CaO}$ & 6.77 & 0.08 & 7.02 & 0.42 \\
$\mathrm{MgO}$ & 3.36 & 0.04 & 3.32 & 0.49 \\
$\mathrm{Na}_{2} \mathrm{O}$ & 3.18 & 0.05 & 3.31 & 0.21 \\
$\mathrm{~K}_{2} \mathrm{O}$ & 1.68 & 0.03 & 1.68 & 0.08 \\
$\mathrm{TiO}_{2}$ & 2.31 & 0.10 & 2.24 & 0.15 \\
\hline
\end{tabular}

${ }^{\mathrm{a}}$ We measured $3940 \mathrm{ppm} \mathrm{Cr}$ in 3 analyses of DTS-1.

The analyses are given in Table 10, together with the norms and modal analyses. Modes were not measured in fine-grained rocks with a high proportion of matrix. In calculating the norms, values of 0.15 per cent $\mathrm{P}_{2} \mathrm{O}_{5}, 0.18$ per cent $\mathrm{MnO}$, and 1.5 per cent $\mathrm{Fe}_{2} \mathrm{O}_{3}$ have been assumed (Kay et al., 1970).

Silica variation diagrams are presented in Figure 22. The basement at DSDP 155 is an alkali basalt; all others are tholeiites. The basalt at four locations $(158,159,160$, 162) are high-alumina tholeiites (Miyashiro et al., 1969); the rest are ordinary tholeiites. DSDP 155 and 158 are low in $\mathrm{CaO} ; 155$ is the highest in $\mathrm{Al}_{2} \mathrm{O}_{3}$. Samples from all sites except 155 and 158 show an increase in $\mathrm{CaO}$ with increasing $\mathrm{Al}_{2} \mathrm{O}_{3}$. There is no apparent covariation of $\mathrm{SiO}_{2}$ and $\mathrm{MgO}$ for the suite as a whole, but the six samples from DSDP 163 show a decrease in $\mathrm{MgO}$ with increasing $\mathrm{SiO}_{2}$. Miyashiro et al. (1969) note a similar relationship in Mid-Atlantic Ridge dredge hauls, and Powers (1955) has noted a similar relationship in rocks of Hawaiian volcanoes. An individual site or volcano shows the decrease of $\mathrm{MgO}$ with increasing $\mathrm{SiO}_{2}$, but several sites or volcanoes taken together do not.

All but one of the DSDP 163 samples are chemically very similar; the single exception is the sample from about $30 \mathrm{~cm}$ below the top of the basalt. This sample is higher in $\mathrm{SiO}_{2}, \mathrm{Al}_{2} \mathrm{O}_{3}, \mathrm{Na}_{2} \mathrm{O}, \mathrm{K}_{2} \mathrm{O}$, and $\mathrm{TiO}_{2}$ and lower in $\mathrm{Fe}_{2} \mathrm{O}_{3}, \mathrm{CaO}$, and $\mathrm{MgO}$ than all the rest. It is the only sample that contains normative quartz. The other five samples show consistent values for $\mathrm{SiO}_{2}, \mathrm{Fe}_{2} \mathrm{O}_{3}, \mathrm{CaO}$, and $\mathrm{Na}_{2} \mathrm{O}$. These samples are very similar in chemical composition to the sideromelane glass and are intermediate in composition between the reddish and opaque globules near the pillow margins. The shallowest of the other five samples is at least 2.3 meters below the top of the basalt. This implies that near-surface samples may not be representative of basalt composition due to weathering or latestage crystallization, and reinforces the need for drill-hole samples taken below the top of the basalt in geochemical studies of oceanic crust.

The East Pacific Rise rocks are much more uniform than the Panama Basin rocks. The Coiba Ridge sample (DSDP 155) is an alkali basalt, similar in many respect to those of Clipperton Island (Engel and Engel, 1964). It should be emphasized, however, that this rock may show the effects of post-extrusive alteration. The high $\mathrm{H}_{2} \mathrm{O}+$ content, in particular, is indicative of low-temperature alteration. It is doubtful whether the alkali-rich character of this rock can be entirely attributed to the composition of the parent magma rather than to halmyrolysis, although preliminary rare earth data (J. Corliss, personal communication, 1972) do indicate that it is the most fractionated of the Leg 16 basalts. The Carnegie Ridge sample (DSDP 157), on the other hand, is very similar to the East Pacific Rise rocks. The apparent heterogeneity of the Panama Basin rocks does not support the view that the three sampled ridges in the Panama Basin were once a single ridge that has been broken up by rifting along the Galapagos Rise (van Andel et al., 1971; this volume, Chapter 35).

Figure 23 shows variations in certain elements and indices with distance from the crest of the East Pacific Rise. With increasing distance from the rise crest $\mathrm{CaO}$ increases, while $\mathrm{TiO}_{2}, \mathrm{~K}_{2} \mathrm{O}$, and $\mathrm{Na}_{2} \mathrm{O}$ decrease. Differentiation index and femic index also decrease away from the ridge crest. It is intresting to note that these trends do not extrapolate to published analyses from the east PacificExperimental Mohole, Clipperton Island, and crest of the East Pacific Rise (Engel and Engel, 1964). The geologic settings of the Clipperton Island and Experimental Mohole samples are sufficiently unlike the "typical" rise flank that their chemical deviation from the Leg 16 trends 
TABLE 10

Chemical Analy ses (Scheidegger), Norms, and Modes (Yeats) of Basalts Collected on DSDP Leg 16

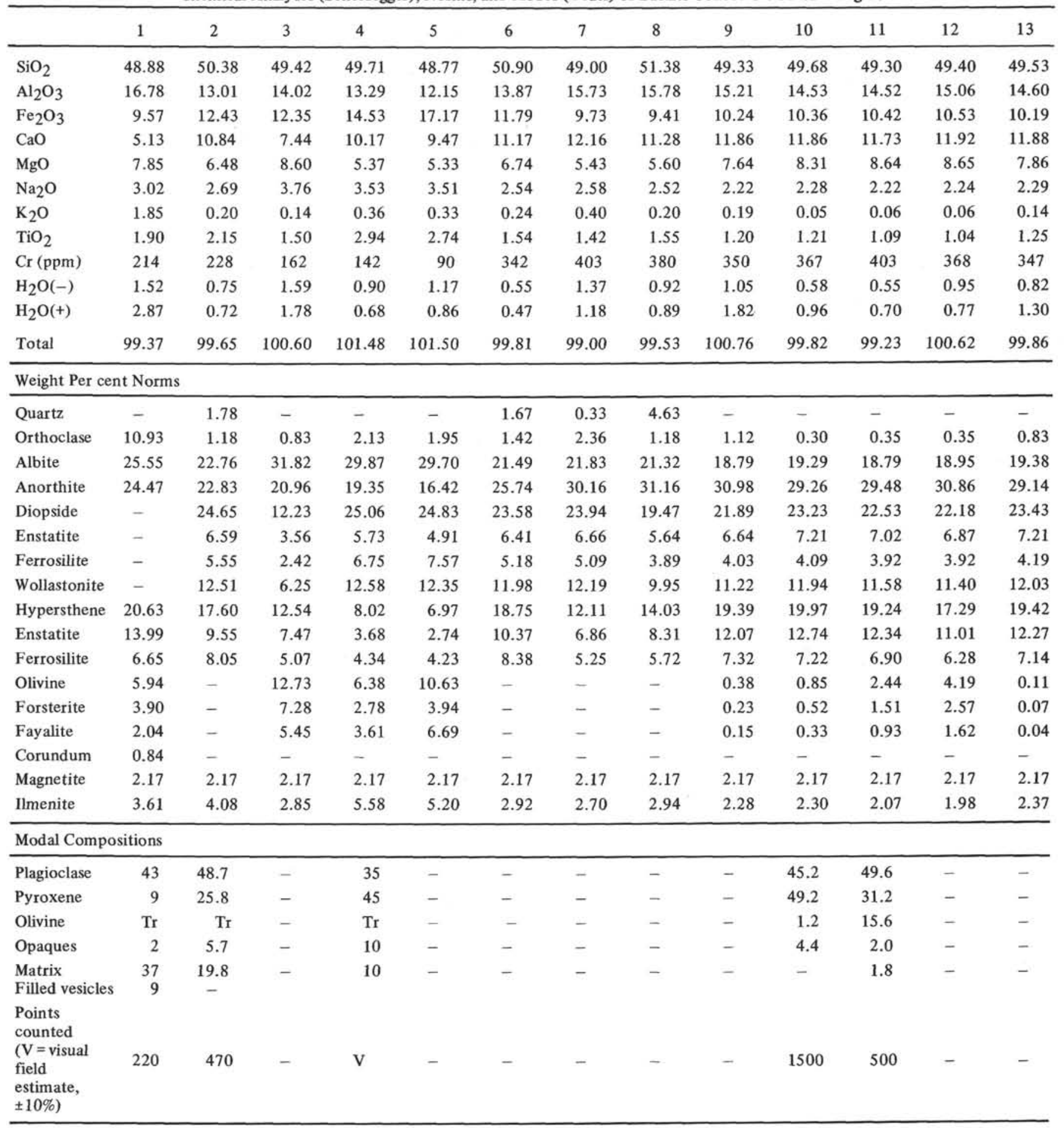

1. $155-12-1(134 \mathrm{~cm})$. Mode from $106-107 \mathrm{~cm} .134 \mathrm{~cm}$ mode is about $40 \%$ plagioclase.

2. $157-49-2(146-148 \mathrm{~cm})$

3. $158-36(C C)$

4. 159-BIT

5. $160-13-1(120-130 \mathrm{~cm})$

6. $161 \mathrm{~A}-15(\mathrm{CC})$
7. $162-17(\mathrm{CC})$

8. 163-28-1, Fragment $4,50 \mathrm{~cm}$

9. 163-29-2, Fragment $10,62-67 \mathrm{~cm}$

10. 163-29-3, Fragment $6,54 \mathrm{~cm}$

11. 163-29-4, Fragment $2,67 \mathrm{~cm}$

12. 163-29-4, Fragment $2,67 \mathrm{~cm}$

13. $163-29-4$, Fragment $4,116 \mathrm{~cm}$ 


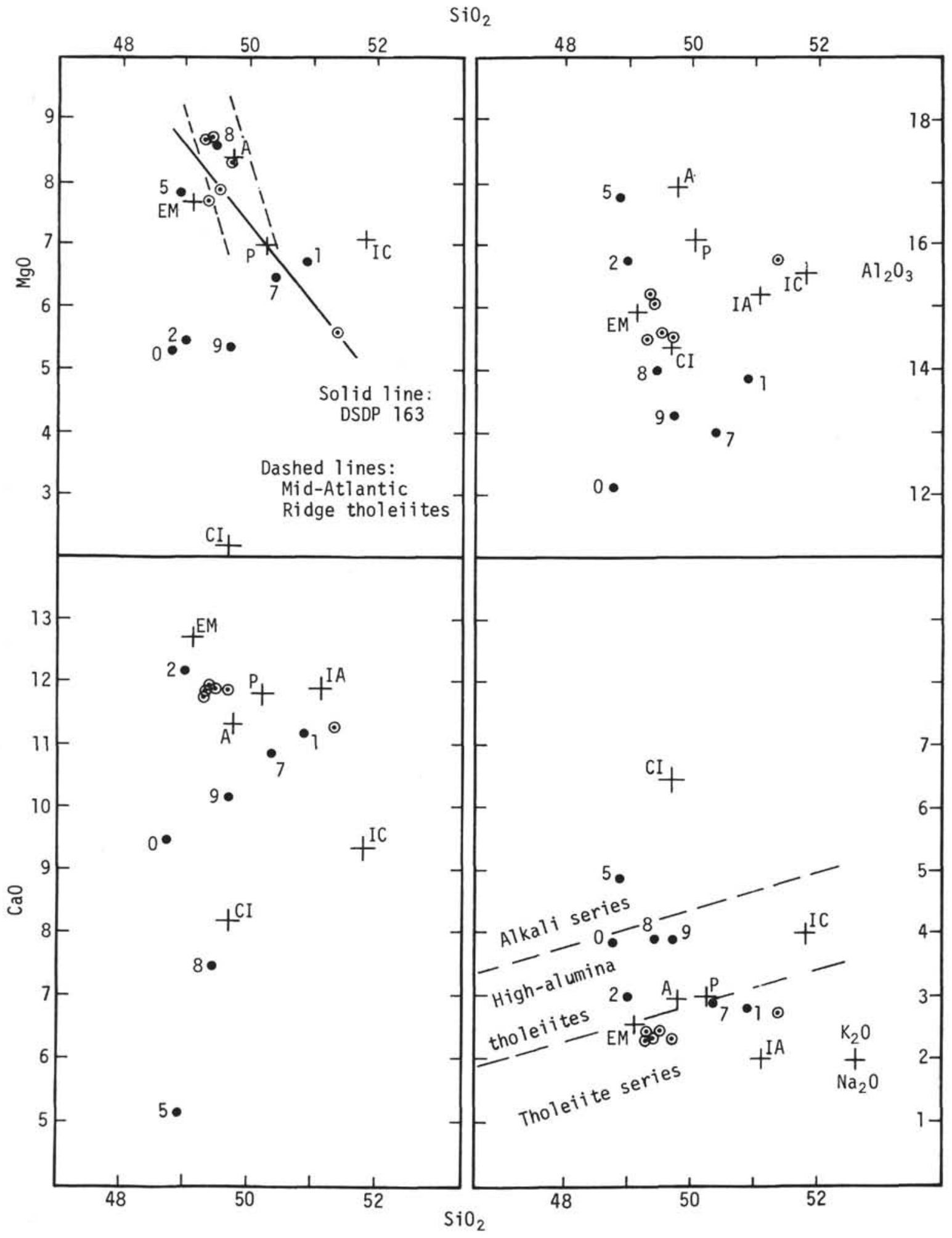

Figure 22. Silica variation diagrams for $\mathrm{Al}_{2} \mathrm{O}_{3}$, total alkalies, $\mathrm{MgO}$, and $\mathrm{CaO}$. Numbers adjacent to points are last digits of Leg 16 DSDP site number, except DSDP 163 which is shown by open circles. MidAtlantic Ridge tholeiite field on $\mathrm{MgO} / \mathrm{SiO}_{2}$ diagram from Miyashiro, et al. (1969). Analyses for comparison, all from Engel and Engel (1964), are: A, average of 7 Atlantic tholeiites; P, average of 5 East Pacific tholeiites; IC, average of 5 Carlsberg Ridge tholeiites; IA, abyssal hill, Indian Ocean; CL, Clipperton Island; EM, Experimental Mohole. 


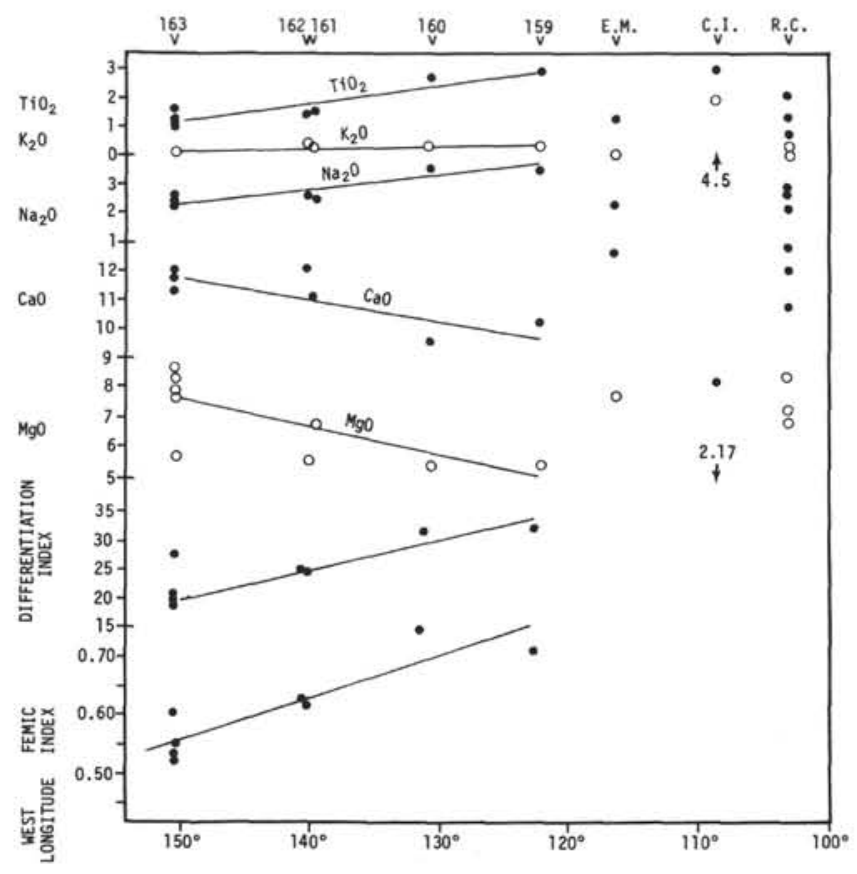

Figure 23. Variations in the concentration of selected major elements, in differentiation index, and in femic index of Leg 16 basalts with distance from the crest of the East Pacific Rise. EM, Experimental Mohole; CI, Clipperton Island; $R C$, rise crest, from Engel and Engel (1964).

is not surprising. In the case of the rise-crest sample, however, the failure to conform could reflect: (a) a temporal change in the composition of the parent mantle material; (b) a change in spreading rate, and hence P-T conditions of magma formation (Scheidegger, 1972); or (c) lateral chemical inhomogeneities in the mantle (Engel and
Engel's samples lie more than $15^{\circ}$ south of the rise flank traverse from which the Leg 16 basalts were collected).

The chemical data, recalculated as cation percentages, are displayed in ternary diagrams showing $\mathrm{Fe}-\mathrm{Mg}$-alkalies (Figure 24), and $\mathrm{Ca}-\mathrm{Mg}-\mathrm{Fe}$ (Figure 25). Normative Or$\mathrm{Ab}-\mathrm{An}$ are shown in Figure 26. These show the cluster of points from DSDP 163, the departure of DSDP 155 from other data, and the similarity of DSDP 157 to the East Pacific Rise flank rocks. No relationship between distance from the rise crest and any of these data is apparent. Comparison between the $\mathrm{Ca}-\mathrm{Mg}$-Fe diagram for pyroxene (Figure 19) and that for bulk rock analyses (Figure 25) shows a relationship between bulk rock and pyroxene composition. The pyroxene and whole rock from DSDP 157 are low in $\mathrm{Fe}$; the pyroxene and whole rock from DSDP 160 are low in Ca.

\section{MINERALOGICAL COMPOSITION}

Despite their comparatively simple mineralogy, deepsea basalts constitute a major problem in quantitative mineralogical analysis. The difficulties arise partly from the wide range of particle sizes present, but mostly from the presence of crystalline phases too small to be identified microscopically. In an attempt to better define the mineralogy of Leg 16 basalts, plagioclase and pyroxene contents of samples from each site (except DSDP 156) were determined by X-ray diffractometry. All samples were run on a Norelco diffractometer at the following settings: $35 \mathrm{kv} ; 30 \mathrm{ma} ; \mathrm{CuK}_{\alpha}$ radiation monochromatized with a diffracted beam graphite monochromator; and slits of $1^{\circ}, 1^{\circ}, 0.1 \mathrm{~mm}$. Data were read at $0.02^{\circ} 2 \theta$ intervals and recorded in digital form on magnetic tape. The digitized data were processed on a CDC 3300 computer to filter out noise and remove background (Rex, 1970) and plotted as working diffractograms.

Quantitative X-ray mineralogy is difficult because: (a) the mass absorption coefficients of samples are variable;

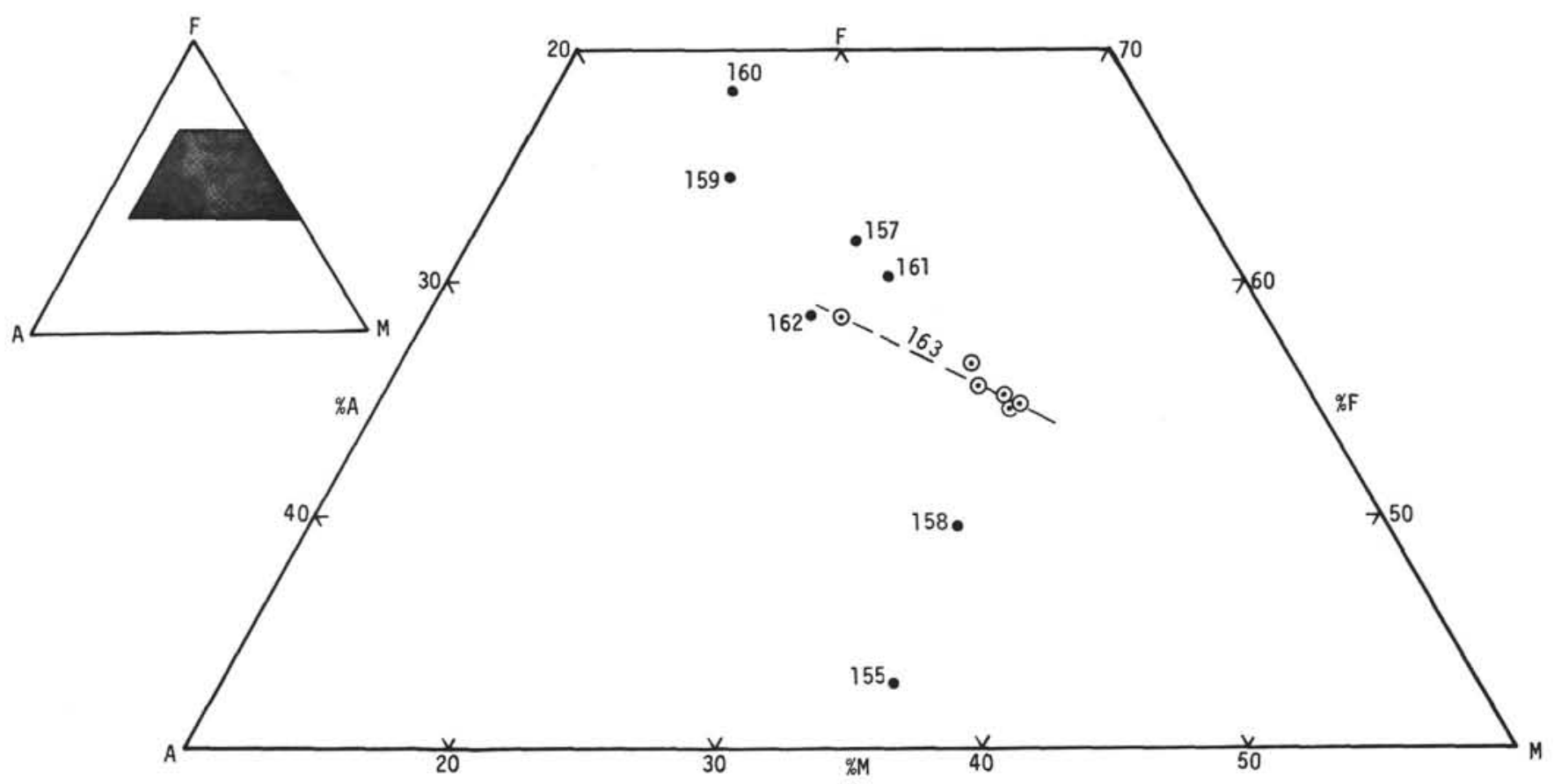

Figure 24. FMA diagram, DSDP Leg 16 basalts. 


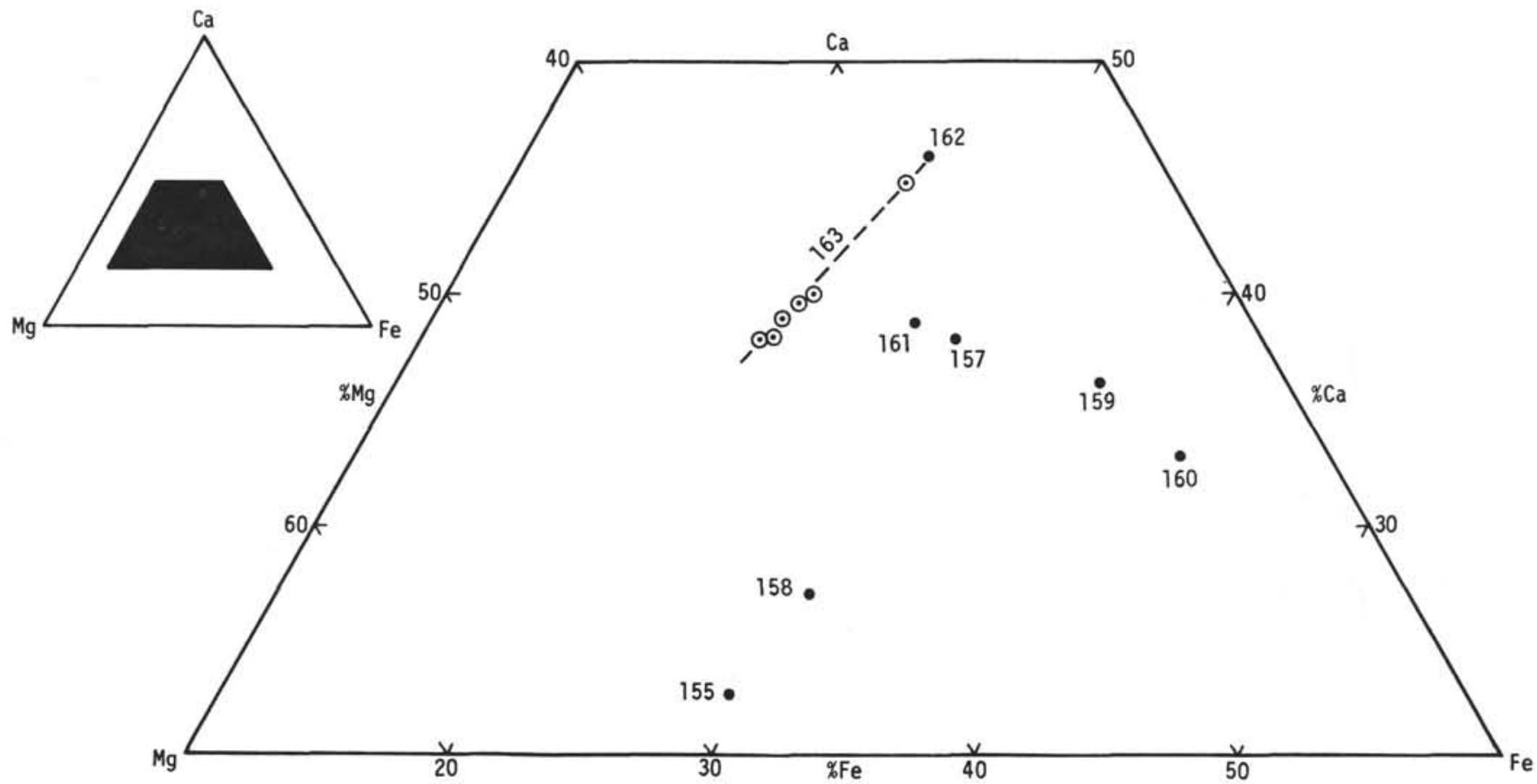

Figure 25. Ternary diagram of atomic per cents $\mathrm{Ca}, \mathrm{Mg}$, and $\mathrm{Fe}$ in DSDP Leg 16 basalts. Compare with pyroxene compositions of Figure 19.

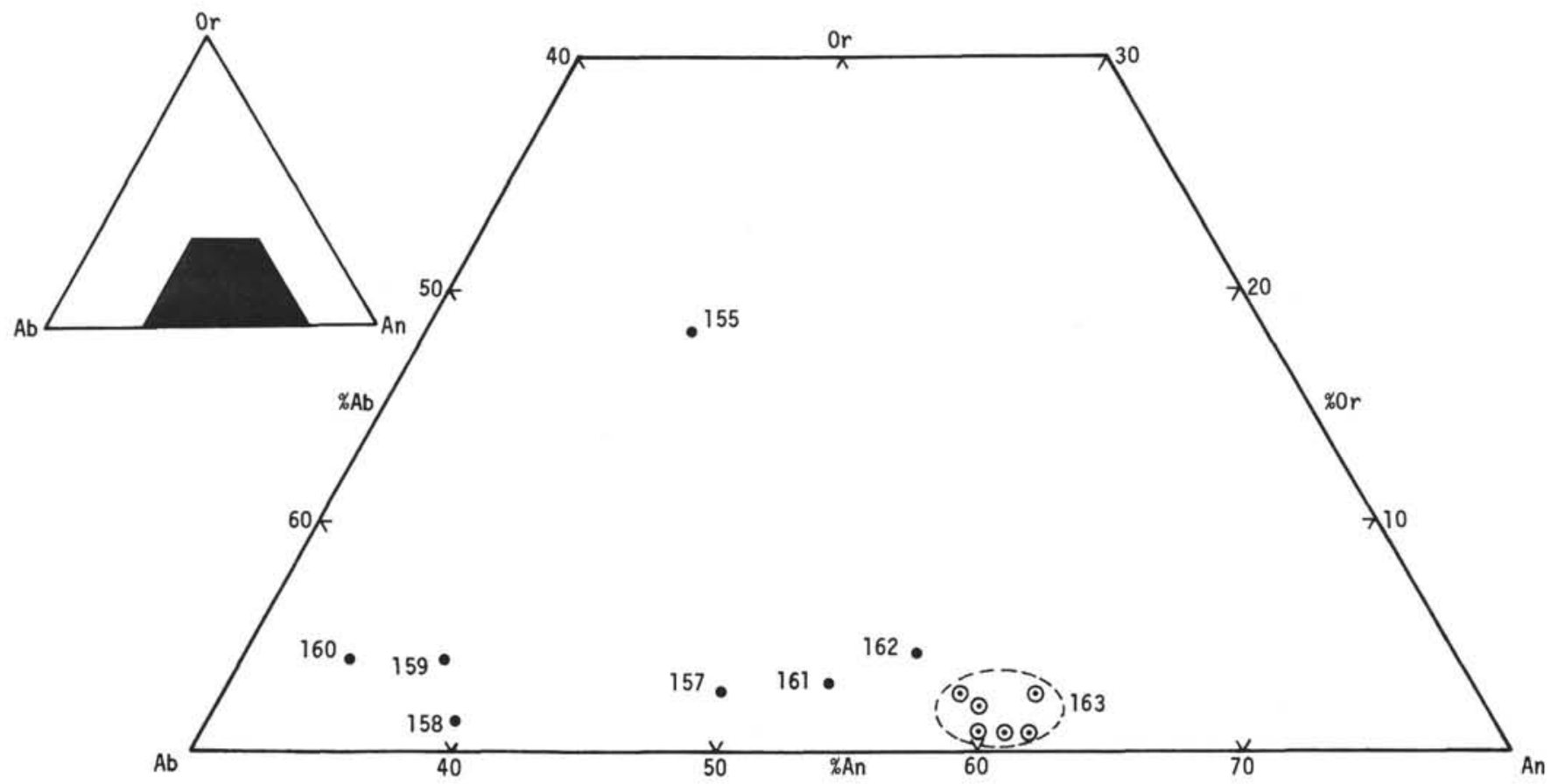

Figure 26. Ternary diagram of normative orthoclase-albite-anorthite in DSDP Leg 16 basalts.

(b) particle size is rarely small enough for a statistically significant number of particles to be at Bragg positions for all reflections, yet large enough for optimum diffraction; and (c) the factors relating the intensities of diffracted maxima to the abundance of a particular mineral are rarely constant or readily determinable.

The first problem is easily solved by comparing peak intensities from a sample with the intensity of a peak of known amount of internal standard. In this study, 50 per cent $\alpha-\mathrm{Al}_{2} \mathrm{O}_{3}$ was added to each sample as an internal standard. The second problem was minimized by grinding each sample for two hours under n-butanol in an automatic grinder. This reduces most particles to the size range 3-20 microns. The powder is pressed against a matte surface at $1000 \mathrm{psi}$ to keep particle orientations relative to the $\mathrm{X}$-ray beam as uniform and reproducible as possible. 
The third problem, that of converting peak intensities to mineral abundances, is the least tractable.

For a mixture of $n$ minerals, the net intensity $\left(I_{i}\right)$ of any diffracted peak of the $i^{\text {th }}$ mineral is given by :

$$
I_{i}=\frac{C_{i} X_{i}}{\rho i \bar{\mu}_{s}}
$$

where $C_{i}$ is a constant for a particular mineral and diffraction system, $X_{i}$ is the weight fraction of $i$ in the mixture, $\rho_{i}$ is the density of $i$ and $\bar{\mu}_{s}$ the mass absorption coefficient of the mixture.

As mentioned above, the mass absorption coefficient of the mixture is eliminated by comparing $I_{i}$ to the intensity of a convenient peak of an internal standard $I_{n}$. The relation is :

$$
\frac{I_{i}}{I_{n}}=\frac{C_{i}}{C_{n}} \cdot \frac{\rho_{n}}{\rho_{i}} \cdot \frac{X_{i}}{X_{n}}
$$

For an experiment where $X_{n}$ (the weight fraction of internal standard) is held constant, this simplifies to :

$$
\frac{I_{i}}{I_{n}}=K_{i n} X_{i}
$$

Thus, the most basic problem in quantitative modal analyses by X-ray diffraction is the determination of $K_{i n}$. $C_{i}$ is affected by structural variations and isomorphous substitutions within a crystal lattice, so that the determination of $K_{i n}$ using pure mineral standards rarely leads to accurate analyses. One method of overcoming the problem is to extract pure minerals from the samples being analyzed (Gibbs, 1967). Such a procedure is at best tedious, and often impossible. Suppose, instead, that a mineral standard $(s)$ whose X-ray character is as similar as possible to that of the same mineral in the unknown is added to the mixture. The equation becomes:

$$
\frac{I_{i+s}}{I_{n}}=K_{i n}^{\prime}\left(X_{i}\left(1-X_{s}\right)+X_{s}\right)
$$

where $X_{s}$ is the weight fraction of standard mineral added and $K_{i n}^{\prime}$ the system constant for the particular $i+s$ mixture. This can be rearranged to:

$$
\frac{I_{i+s}}{I_{n}}=K_{i n}^{\prime} X_{i}+K_{i n}^{\prime}\left(1-X_{i}\right) X_{s}
$$

$$
\text { Clearly, as } \quad X_{s} \rightarrow O, \frac{I_{i+s}}{I_{n}} \rightarrow \frac{I_{i}}{I_{n}}
$$

and $K_{i n}^{\prime} \rightarrow K_{i n}$. Thus, a plot of

$$
\frac{I_{i+s}}{I_{n}} v X_{s}
$$

has an intercept of $K_{i n} X_{i}$ and a limiting slope (at $X_{s}=0$ ) of $K_{i n}\left(1-X_{i}\right)$. If these two characters of the curve can be measured accurately, both $K_{\text {in }}$ (for the suite of samples) and $X_{i}$ (for the particular sample) can be calculated.

a limiting slope (at $X_{s}=0$ ) of $K_{i n}\left(1-X_{i}\right)$. If these two characters of the curve can be measured accurately, both
$K_{i n}$ (for the suite of samples) and $X_{i}$ (for the particular sample) can be calculated.

The importance of selecting a mineral standard similar in character to the unknown is obvious. If the two are identical, the last equation becomes a straight line, if they are very dissimilar, the curve will change slope rapidly close to the $y$-axis, thereby making accurate slope and intercept determinations impossible.

The $K_{\text {in }}$ values for plagioclase and pyroxene with an $\alpha$-alumina internal standard were determined from plots of the last equation using additions of bytownite from Crystal Bay, Minnesota, and pigeonite from Cedar Butte, Oregon, to basalt sample 163-29-3(54). Both plots had little curvature and yielded $K_{\text {in }}$ values of 2.90 and 0.44 respectively.

The results of the X-ray determinations, together with petrographic modes (Yeats, Table 10, and Christensen, Chapter 24) and norms (Scheidegger, Table 10) are listed in Table 11. In the least-altered samples, the plagioclase values agree well, but the $\mathrm{X}$-ray pyroxene values are lower than the norms or petrographic modes. In the altered samples, there is little coherence between the various methods, with X-ray modes tending to be lower than petrographic values. In these rocks, partial alteration of pyroxenes that may not be visible under the microscope will be reflected in unexpectedly low X-ray modes. Overall, the agreement between plagioclase determinations by the three methods is better than between pyroxene determinations. Further work on variances within methods for deep-sea basalts appears necessary, however, before differences can be attributed to geochemical and petrographic factors rather than to errors associated with the methods themselves.

\section{CONCLUSIONS}

Basalt was recovered at enough sites on Leg 16 to permit preliminary conclusions about the petrology and geochemistry of the sediment-covered western flank of the East Pacific Rise and of three aseismic ridges of the Panama Basin. Recovery of a long, nearly continuous section at DSDP 163 has revealed field relationships and mode of emplacement of individual basalt cooling units for the first time. The most significant preliminary observations are summarized below.

1. All samples analyzed are tholeiites except that from the Coiba Ridge, which is an alkali basalt. The East Pacific Rise flank rocks are more homogeneous chemically than the Panama Basin rocks.

2. All samples from DSDP 163 except the one taken near the top of the basalt are chemically uniform, suggesting that deep penetration is not necessary to get through the severely altered layer at the basalt surface. All the sideromelane analyses, even those from near-surface samples, are similar to the bulk rock analyses from Core 29 , suggesting that in samples achieving only shallow penetration of basalt, analyses of sideromelane may be more representative of crustal composition than bulk rock analyses. Moore (1966) has reported that palagonite forms from sideromelane upon extended exposure of the pillow surface to sea-water. The absence of palagonite crusts suggests that the DSDP 163 pillows were exposed to seawater for only a short time. The uniform slight alteration evident 
PETROLOGY AND GEOCHEMISTRY OF BASALTS, EASTERN EQUATORIAL PACIFIC

TABLE 11

Comparison of Modal and Normative Concentrations of Plagioclase and Pyroxene in DSDP Leg 16 Basalts

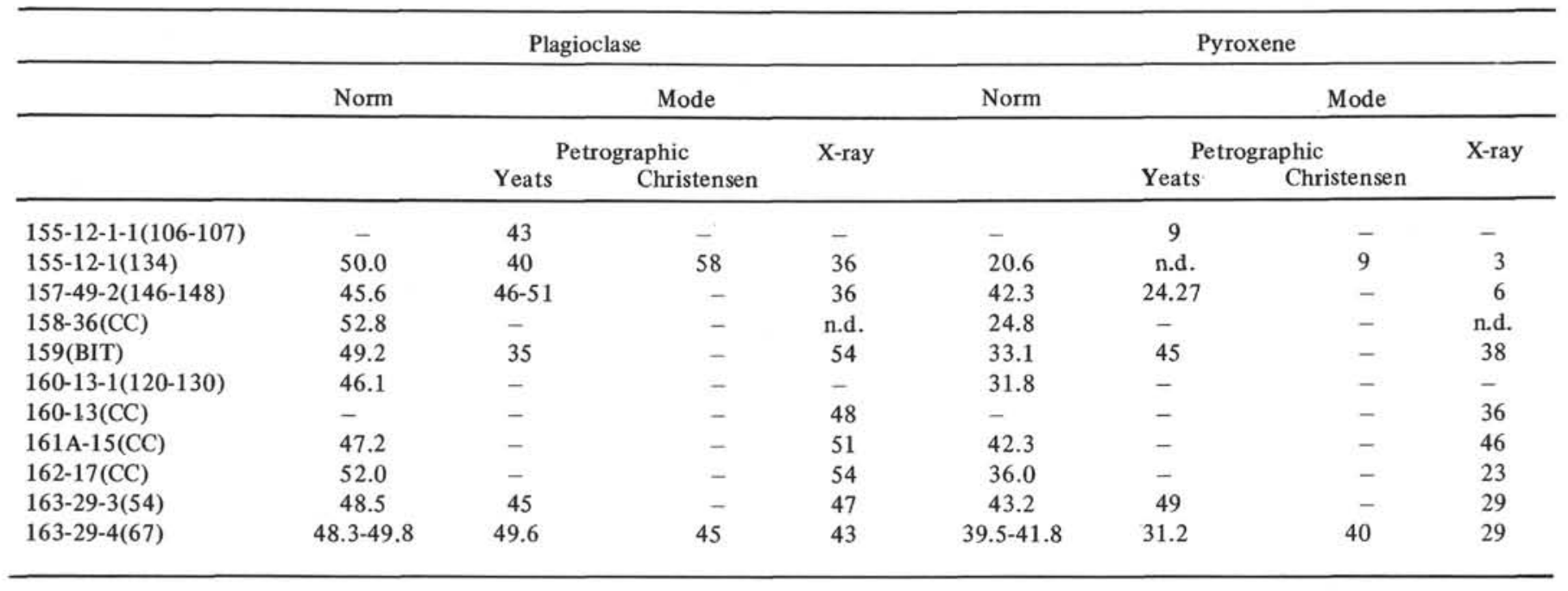

at depth, probably a weathering phenomenon extending from flow boundaries and shrinkage fractures, may affect the entire seismic second layer beneath the oceans. Only much deeper penetration of basement can resolve this question.

3. The Leg 16 samples show systematic decreases in $\mathrm{TiO}_{2}$ and $\mathrm{Na}_{2} \mathrm{O}$ and an increase in $\mathrm{CaO}$ with distance from the rise crest. However, these trends do not extrapolate to values measured further south at the present rise crest.

4. The order of major mineral formation at all sites is (a) olivine, (b) calcic plagioclase, and (c) augite, opaques, and more sodic plagioclase.

5. Variations in the birefringence and extinction angles of augite crystals are attributed to variations in chemical composition, particularly $\mathrm{Al}_{2} \mathrm{O}_{3}, \mathrm{TiO}_{2}$, and $\mathrm{Na}_{2} \mathrm{O}$. The compositional variation is, in many cases, complicated by incipient exsolution of orthopyroxene or pigeonite. Compositional boundaries tend to be abrupt, suggesting a domain character of crystallization.

6. Olivine phenocrysts are $\mathrm{Mg}$-rich $\left(\mathrm{Fo}_{85-87}\right)$ and contain very small smounts of $\mathrm{MnO}$ and $\mathrm{TiO}_{2}$.

7. Most plagioclase crystallized after emplacement, although some pre-emplacement plagioclase, mostly calcic labradorite with narrow, normally zoned rims, is also found. In larger plagioclase grains, low-amplitude euhedral oscillatory zoning is present. The plagioclase contains 0.5-1.2 per cent iron, suggesting the possible presence of a $\mathrm{NaFe}^{+3} \mathrm{Si}_{3} \mathrm{O}_{8}$ component.

8. Opaque minerals commonly form octahedral chains rather than individual anhedra. They are magnetically unstable (Heinrichs, this volume, Chapter 23). Two analyzed opaque crystals from DSDP 157 and 163 contain 22 per cent $\mathrm{TiO}_{2}$ and have an $\mathrm{Fe}^{+3}: \mathrm{Fe}^{+2}$ ratio of 2:1.

9. Filled vesicles were found near the top of the basalt at all sites. Vesicle diameters do not appear to be related to present water depth.

10. The basalt at DSDP 163 is clearly extrusive based on core relationships and on the absence of metamorphism or metasomatism of overlying sediments. Cooling units have sideromelane-bearing margins which dip at 15 to $70^{\circ}$, suggesting that the units are more like pillows than tabular flows. The degree of alteration, number of calcite veins, and number of vesicles decrease from the margins inward; the grain sizes of plagioclase and pyroxene increase. Plagioclase composition and olivine grain size remain constant from margin to center. The centers of the cooling units are texturally diabases.

11. The similarity in chemical composition between the sideromelane and the bulk rock at DSDP 163 indicates that the rapidly quenched pillow margins are representative of the chemical composition of at least the upper 18 meters of basalt. The reddish and opaque globules show a differentiation in composition with respect to sideromelane; with respect to $\mathrm{Fe}$ and $\mathrm{Mg}$, the reddish globules are relatively enriched in alkalies and in $\mathrm{Ca}$, and the opaque globules are correspondingly deficient in these elements. The chemical composition of the globule zone, based on modal analysis of reddish and opaque globules, is the same as the composition of the sideromelane and of the bulk rock. It is apparent that the pillows have differentiated in place into crystallite-bearing globules of two distinct compositions; with slower cooling, these globules form plagioclase-rich and pyroxene-rich areas in the interior of the pillow. Gravity appears to play no part in the distribution of the globules.

12. The spherical shape of the DSDP 163 globules and their abrupt boundaries with one another suggest that the magma may have split into immiscible fractions during cooling, with the surface tension of the globules being greater than that of the sideromelane. The tendency of the globules to coat grains of plagioclase preferentially to olivine suggests further that the interfacial tension between globule and plagioclase was lower than that between globule and olivine at the time of quenching. Experimental evidence supporting the theory of liquid immiscibility in silicate magmas has been presented by Ferguson and Currie (1972), Roedder and Weiblen (1970), and Philpotts and Hodgson (1968). The immiscible liquids produced by Ferguson and Currie closely approach the compositions of the globules analyzed in this study. However, the $\mathrm{Na}: \mathrm{Ca}$ content of the opaque globules is different from that required for a liquid in equilibrium with the enclosed plagio- 
clase microlites. This fact suggests that the globules resulted from spherulitic crystallization rather than liquid immiscibility.

\section{REFERENCES}

Albee, A.L. and Chodos, A.A., 1970. Semiquantitative electron microprobe determinations of $\mathrm{Fe}^{+2} / \mathrm{Fe}^{+3}$ and $\mathrm{Mn}^{+2} / \mathrm{Mn}^{+3}$ in oxides and silicates and its application to petrologic problems. Am. Mineralogist. 55, 491.

Bonnichsen, B., 1969. Metamorphic pyroxenes and amphiboles in the Biwabik Iron Formation, Dunka River area, Minnesota. Min. Soc. Am. Spec. Paper 2, 217.

Bryan, W.B., 1972. Textural and mineralogical relations of basalts from Sites 100 and 105. In Hollister, C.D., and Ewing, J.I., 1972. Initial Reports of the Deep Sea Drilling Project, Volume 11. Washington (U.S. Government Printing Office). 873.

Corliss, J.B., 1971. The origin of metal-bearing submarine hydrothermal solutions. J. Geophys. Res. 76 (33), 8128.

Deer, W.A., Howie, R.A. and Zussman, J., 1963. Rock forming silicates: Framework silicates. 4. London (Longmans).

Engel, A.E.J. and Engel, C.G., 1964. Igneous rocks of the East Pacific Rise. Science. 146, 477.

Ferguson, J. and Currie, K.L., 1972. Silicate immiscibility in the ancient "basalts" of the Barberton Mountain Land, Transvaal. Nature Physical Science. 235, 86.

Flanagan, F.J., 1969. U.S. Geological Survey Standards - II. First compilation of data for the new U.S.G.S. rocks. Geochim. Cosmochim. Acta. 33, 81.

Gibbs, R.J., 1967. Quantitative X-ray diffraction analysis using clay mineral standards extracted from the samples to be analyzed. Clay Mins. 7, 79.

Holden, J.C. and Dietz, R.S., 1972. Galapagos gore, Nazcopac triple junction and Carnegie/Cocos Ridges. Nature. 235, 266.

Kay, R., Hubbard, N.J. and Gast, P.W., 1970. Chemical characteristics and origin of oceanic ridge volcanic rocks. J. Geophys. Res. 75, 1585.

Miyashiro, A., Shido, F. and Ewing, M., 1969. Diversity and origin of abyssal tholeiite from the Mid-Atlantic Ridge near $24^{\circ}$ and $30^{\circ}$ North Latitude. Contr. Mineral. and Petrol. 23. 38 .
Morgan, W.J., 1971. Convection plumes in the lower mantle. Nature. 230, 42.

Moore, J.G., 1966. Rate of palagonitization of submarine basalt adjacent to Hawaii. U.S. Geol. Survey Prof. Paper 550-D, D163.

Muir, I.D. and Tilley, C.E., 1964. Basalts from the northern part of the rift zone of the Mid-Atlantic Ridge. J. Petrol. 5, 409.

Murray, J. and Renard, A.F., 1891. Report on deep-sea deposits, based on the specimens collected during the voyage of H.M.S. "Challenger" in the years 1872-76. London.

Omang, S.H., 1969. A rapid fusion method for decomposition and comprehensive analysis of silicates by atomic absorption

Omang, S.H., 1969. A rapid fusion and method for decomposition and comprehensive analysis of silicates by atomic absorption spectrophotometry. Anal. Chim. Acta. 46, 225.

Peacock, M.A. and Fuller, R.E., 1928. Chlorophaeite, sideromelane and palagonite from the Columbia River plateau. Am. Mineralogist. 13, 360.

Philpotts, A.R. and Hodgson, C.J., 1968. Role of liquid immiscibility in alkaline rock genesis. Intern. Geol. Cong. 23rd 2, 175.

Powers, H.A., 1955. Composition and origin of basaltic magma of the Hawaiian Islands. Geochim. Cosmochim. Acta. 7, 77.

Rex, R.W., 1970. Shore-based laboratory procedures (X-ray mineralogy). In Bader, R.G., Gerard, R.D. et. al., 1970. Initial Reports of the Deep Drilling Project, Volume IV. Washington (U.S. Government Printing Office). 748.

Roedder, E. and Weiblen, P.W., 1970. Silicate liquid immiscibility in lunar magmas, evidenced by melt inclusions in lunar rocks. Science. 167, 641 .

Rucklidge, J.C. and Gasparrini, E.L., 1969. EMPADR VII Electron microprobe analytical data reduction program Version 7. Department of Geology, University of Toronto, Toronto, Canada.

Scheidegger, K.F., 1972. Temperatures and compositions of magmas ascending beneath actively spreading mid-ocean ridges. Ph.D. Dissertation. Oregon State Univ. 143 p.

van Andel, Tj. H., Heath, G.R., Malfait, B.T., Heinrichs, D.F. and Ewing, J., 1971. Tectonics of the Panama Basin, eastern equatorial Pacific. Bull. Geol. Soc. Am. 82, 1489.

Zies, E.G., 1966. A new analysis of cossyrite from the island of Pantelleria. Am. Mineralogist. 51, 200. 